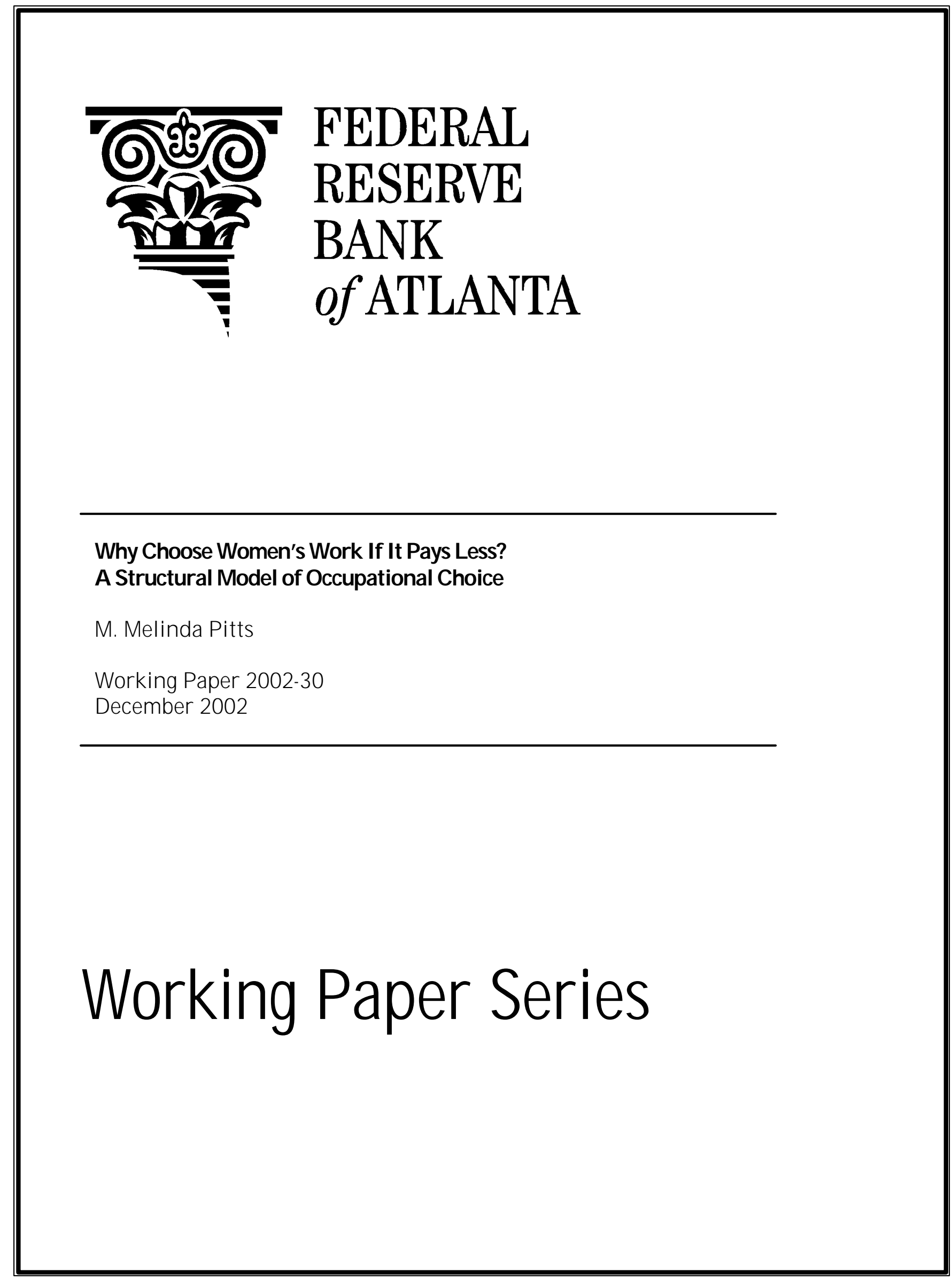


Federal Reserve Bank of Atlanta

Working Paper 2002-30

December 2002

\title{
Why Choose Women's Work If It Pays Less? A Structural Model of Occupational Choice
}

\author{
M. Melinda Pitts, Federal Reserve Bank of Atlanta
}

\begin{abstract}
This paper controls for the selection bias associated with occupational choice and the labor force participation decision in estimating the wage penalty for working in female-dominated occupations. Using data from the May 1979 and the April 1993 supplements to the Current Population Survey, the author finds that women working in female-dominated occupations have similar or higher expected wages in their chosen occupation compared to nonfemale-dominated occupations. This result indicates that there is efficient matching between occupations and skills for women in the labor force and refutes the theories of occupational segregation or crowding as determinants of the gender wage differential.
\end{abstract}

JEL classification: J 24, J 16

Key words: occupational choice, gender wage differential, selection bias

The author gratefully acknowledges Brian Amour, Robert Clark, Julie Hotchkiss, Ann McDermed, Bob Moore, Paula Stephan, and Laura Taylor. The views expressed here are the author's and not necessarily those of the Federal Reserve Bank of Atlanta or the Federal Reserve System. Any remaining errors are the author's responsibility.

Please address questions regarding content to M. Melinda Pitts, Research Department, Federal Reserve Bank of Atlanta, 1000 Peachtree Street, N.E., Atlanta, Georgia 30309-4470, 404-498-7009, melinda.pitts@atl.frb.org.

The full text of F ederal Reserve Bank of Atlanta working papers, including revised versions, is available on the Atlanta F ed's Web site at http:// www.frbatlanta.org. Click on the "Publications" link and then "Working Papers." To receive notification about new papers, please use the on-line publications order form, or contact the Public Affairs Department, Federal Reserve Bank of Atlanta, 1000 Peachtree Street, N.E., Atlanta, Georgia 30309-4470, 404-498-8020. 
Why Choose Women's Work if it Pays Less? A Structural Model of Occupational Choice*

\section{INTRODUCTION}

It is well-known that the majority of women work in a limited number of occupations characterized by a proportionately high number of female workers. Moreover, workers in these female-dominated (FD) occupations earn less, on average, than workers in traditionally male or integrated occupations (McPherson and Hirsch 1995). This occupational wage differential is widely accepted as a partial explanation for the pervasive gender wage-differential. However, it is unclear why an individual would enter into a FD occupation if the wages are lower than in nonfemale-dominated (NFD) occupations. It is also unclear if women who choose FD occupations could earn more in occupations that are NFD. Therefore, attributing a portion of the gender wage differential to occupational differences may be incorrect. Indeed, differences in the occupational choices of men and women will only explain the wage differential between genders if females in FD occupations could expect to earn higher wages elsewhere.

Occupational segregation by gender and the gender wage differential have been the focus of much empirical research, with the majority of work using data from the 1970s and early 1980s. The consensus is that a negative relationship exists between the percentage female in an occupation and the wage. Many of these studies, however, are plagued by problems associated with selection bias arising from the endogeneity of the occupational choice and work decisions to one's wage. If the error terms of the occupational choice and work decision equations are correlated with the error term in the wage equation, this could lead to biased coefficient estimates. Furthermore, while many studies have shown that workers in FD occupations earn 
less than workers in other occupations, there is little evidence concerning whether workers in these FD occupations would be better or worse off in other occupations.

This study controls for the selection bias on wages associated with occupational choice and the work decision by estimating a bivariate probit with selection as the first stage and the wage estimation as the second. This is accomplished using data from the May 1979 and April 1993 supplements of the Current Population Survey. In order to capture any penalty for working in a typically female occupation, a wage differential between FD and NFD occupations is estimated using the predicted wage for each individual in each occupation. Contrary to earlier research, the results indicate that women are not choosing the occupation that pays less when they enter a FD occupation. In fact, for the most part, women who choose to work in FD occupations receive a wage premium for doing so. This result, in effect, indicates that there is efficient matching between occupations and skills for the women in the labor force. Furthermore, it refutes the explanation that occupational segregation or crowding explains part of the gender gap in wages, as the gender gap would be larger if more women worked in NFD occupations.

As the results in this research differ from much of the earlier research, I also estimate a model which is similar to previously reported models that do not control for selection bias. The results of this estimation indicate a penalty for entering a FD occupation for all workers, which is consistent with earlier findings. This outcome supports the argument that self-selection matters and indicates that the selection model results are not merely a product of the data. 
Finally, the estimated wage differential from the selection model is included in a structural model of occupational choice. The results indicate that the wage penalty is a dominating factor in the occupational choice decision, thus mitigating support for occupational crowding due to discriminatory hiring practices as an explanation for the different choices in occupations.

A review of previous literature is in section two, followed by the theoretical and empirical models in sections three and four, respectively. A description of the data is included in section five, followed by the estimation procedures in section six, the results in section seven, and the conclusion in section eight.

\section{PREVIOUS RESEARCH}

Two key economic theories have commonly been used to explain occupational segregation and the resulting wage differential: gender differences in human capital and occupational crowding. Polachek and Siebert (1993) narrow human capital theory to focus specifically on the impact of intermittent labor force participation. They propose that women anticipating periods of absence may invest less in human capital and that acquired skills will depreciate during these spells of absence from the labor force. The implication is that because women have more intermittent participation than men, women choose occupations that have a lower atrophy rate of skills and flatter earnings profiles. While this earnings profile minimizes the penalty for absence from the labor force and maximizes the woman's lifetime earnings, it results in lower relative wages when compared to men. 
Blau, Ferber, and Winkler (1998) suggest that women may also limit their pursuit of human capital because of social influences that cause the women to make choices that may adversely affect their labor market outcomes. ${ }^{1}$ In addition, the authors note that direct labor market discrimination lowers the return to human capital and thus lowers the incentive to invest. Polachek (1995) indicates that societal discrimination, in the form of division of labor in the home, also further reduces the incentive for women to invest in human capital.

Bergmann (1974) hypothesizes that discriminatory hiring practices which prevent women from entering a large number of available occupations have resulted in women being crowded into a small number of occupations. This occupational crowding leads to an excess supply in these occupations, and hence, lower market wages. In general, past research (Chiswick et al. (1975), Johnson and Solon (1986), Blau and Beller (1988), and Sorenson (1990), among others) has found occupational segregation to explain a portion of the wage differential between genders.

Chiswick et al. (1975), using data from the 1970 Census, found that if white women have the same occupational distribution as white men, the earnings of white women would increase by 15 percent. However, for single women who have never been married there is no benefit to changing the occupational distribution. This implies that the wage differential for this group is not attributed to occupational segregation.

Blau and Beller (1988), using data from the 1981 Current Population Survey, estimate a $\log$ annual earnings equation for white individuals. In addition to controlling for education, 
potential work experience, geographic characteristics, marital status, and part-time work status, they include two dummy variables to control for the percent female in the individual's chosen occupation. The first dummy variable is equal to one if the occupation is at least 70 percent male (a male-dominated occupation), and the second is equal to one if the occupation is between 40 and 70 percent male (an integrated occupation). Their results indicate that women in maledominated occupations have 16 percent higher earnings and women in integrated occupations have nine percent higher earnings compared to women in FD occupations. Blau and Beller (1988) also estimate the same equation separately for men and find that men in FD occupations earn 27 and 16 percent less than men in male-dominated and integrated occupations, respectively.

Sorenson (1990), uses the 1984 Panel Study of Income Dynamics and the May/June 1983 Current Population Survey to examine the affect the proportion of female workers in an individual's chosen occupation has on hourly earnings. Sorenson (1990) finds that between 20 and 23 percent of the wage gap is attributed to the percentage of workers in the occupation that are female, after controlling for differences in human capital and industry. In a similar analysis, Johnson and Solon (1986), using data from the May 1978 Current Population Survey, find that the percent female in an occupation explains 14 percent of the earnings gap.

McPherson and Hirsch (1995) explain part of the negative relationship between wages and working in a female-dominated occupation using data from the Current Population Survey Outgoing Rotation Group from January 1983 to December 1993. They determine that 
differences in worker and occupational characteristics explain two-thirds of the gender composition effect for women and four-fifths for men. Therefore, they conclude that the key issue is the wage differential between genders and not the occupational wage gap.

A major shortcoming of these studies is that treating the gender composition of one's chosen occupation as an exogenous variable in the wage equation means there is no control for the self-selection of individuals into different occupations. In addition, the selection bias associated with the decision to enter the labor force is largely ignored as well. Sorenson (1989) controlled for this potential self-selection by estimating a bivariate probit for the decision to work and the decision to enter the labor force as the first stage and the wage equations for FD occupations and other occupations as the second stage, using data on women from the 1984 Panel Study of Income Dynamics. Sorenson(1989) finds a positive sign on the occupational selection bias variable in the wage equations, indicating that workers enter the occupation to which they are best suited. When Sorenson (1989) breaks down the average wage differential, calculated at the sample means, she finds that females in FD occupations would expect to earn between six and fifteen percent more in male-dominated occupations, dependant upon the specification of the wage equation. However, there are a few shortcomings to this paper that lend doubt to these results. First, the reduced form estimate of the occupational choice decision does not include all job related information that is included in the wage equations, such as industry, union status, geographical location, self-employment status, and job tenure. Therefore, the reduced form model does not fully control for the expected wage differential between the two 
occupational groups. In addition, the data does not include information on nonpecuniary benefits such as pension, health insurance, and disability benefits.

\section{THEORETICAL MODEL}

The theoretical model builds upon the foundation of Atrostic (1982) and Killingsworth and Heckman (1986). Atrostic (1982) examines the joint demands for leisure and nonpecuniary job characteristics and theorizes that an individual's total compensation from work (assumed to be constant across firms) is the sum of the money wage compensation and the compensation from job characteristics. While the total compensation is constant, the mix of money wages and job characteristics varies across firms. Therefore, when choosing a job, an individual chooses the utility maximizing combination of wages and job characteristics. Atrostic modifies the standard utility maximization model to account for this wage-job characteristic tradeoff. This is done by allowing an individual's utility to be a function of not only leisure time and consumption of market goods, but job characteristics as well. The individual then chooses a combination of hours of work, consumption goods, and job characteristics that maximizes total utility. In their review of Atrostic's work, Killingsworth and Heckman (1986) build upon this model by treating job characteristics the same as consumption goods. They assume that the individual buys desirable job characteristics at a cost of lower wages or accepts undesirable job characteristics in order to receive higher wages.

This model extends the work of Killingsworth and Heckman (1986). ${ }^{2}$ The individual is assumed to simultaneously choose the utility maximizing levels of leisure time, L, the 
composite market consumption good $\mathbf{X}_{1}$, and a set of additional consumption goods that are job characteristics consumed per hour of work, $\mathbf{X}_{2}$ :

$$
U=U\left(L, \boldsymbol{X}_{1}, \boldsymbol{X}_{2}\right)
$$

subject to a time constraint of

$$
T=L+H
$$

and a budget constraint of

$$
\boldsymbol{P}_{1} \boldsymbol{X}_{1}=H W_{M}+Y .
$$

The vector of purchased goods and services, $\mathbf{X}_{1}$, are purchased at price $\mathbf{P}_{1}$. Time is allocated between nonmarket activities and market work, where $\mathrm{L}$ is the number of hours per period spent on leisure or nonmarket work, $\mathrm{H}$ is the number of hours per period spent on market work, and $\mathrm{T}$ is the total number of hours available per period. The hourly money wage rate is given by $\mathrm{W}_{\mathrm{M}}$ and $\mathrm{Y}$ is exogenous money income.

In addition to choosing the utility maximizing level of consumption goods and leisure, an individual may also choose nonpecuniary job characteristics. The levels of nonpecuniary job characteristics, $\mathbf{X}_{2}$, are utility increasing. ${ }^{3}$ There is an inverse relationship between these job characteristics and the money wage an individual receives. Thus if the individual purchases a job characteristic, the price paid is reduced money wages and the gain is increased utility. The resulting hourly wage rate is defined as: 


$$
W_{M}=W(\boldsymbol{Z})-\boldsymbol{P}_{2} \boldsymbol{X}_{2} .
$$

The neutral wage, $\mathrm{W}(\mathbf{Z})$, is the hourly wage an individual would receive if $\mathbf{X}_{2}$ were equal to zero. The neutral wage is solely a function of the individual's human capital, $\mathbf{Z}$. The individual decreases the value of his or her monetary wage when he or she buys $\mathbf{X}_{2}$ at a price of

$\mathbf{P}_{2}$ per hour of work or $\mathrm{HP}_{2} \cdot{ }^{4}$ Therefore, if men and women, on average, have different preferences for job characteristics then one would expect men and women to purchase different types of job characteristics and select into different occupations. If the job characteristics women purchase are, on average, more costly than those purchased by men, then it would also be expected that average wages for women would be lower.

\section{EMPIRICAL MODEL}

The theoretical model suggests that the choice of job characteristics are both endogenous to the labor force participation decision and directly related to the money wage an individual receives. However, there are a limited number of job characteristics typically reported in the data and the ones that are available are objective, such as the availability of a pension plan or employer-sponsored health insurance. There is generally no subjective information readily available to quantify an individual's tastes and preferences concerning issues such as the type of workplace, coworkers, or duties performed.

Nevertheless, one can assume that the occupation an individual chooses reflects the utility-maximizing tradeoff between wages and job characteristics. As the focus of this research 
is gender differences in the labor force, the gender distribution of an individual's occupation is used as a proxy for the bundle of job characteristics that makes the job attractive to that individual. For example, an individual who prefers characteristics associated with a typically female occupation will be more likely to enter a FD occupation than someone who prefers characteristics associated with a typically male occupation, ceteris paribus. Previous empirical evidence indicates that women and men do, on average, choose different types of occupations which suggests that women and men have different utility-maximizing choices of occupation.

Killingsworth and Heckman (1986) point out that the occupational choice decision, in a world with heterogeneous jobs, is endogenous to the participation decision because occupation is chosen along with participation. This endogeneity implies that individuals have complete information regarding their opportunities in the labor force and take into account occupational characteristics when deciding whether to enter the labor force. Furthermore, when examining heterogenous labor supply of men, Killingsworth (1985) found a significant relationship between labor supply and discrete job choices. However, when Sorenson (1989) estimated the pay disparity for women between typically female occupations and other occupations, she found the correlation coefficient to be insignificant. As there is no consensus in the literature, and since the theoretical model indicates that there is a relationship, the work decision and occupational choice will be estimated together.

The individual has two questions to consider: (1) what occupation will provide he or she the most utility; and (2) are the gains from working in that occupation greater than the costs? In 
other words, the individual must choose whether the market wage they would earn in their chosen occupation, $W_{m i}$, is greater than the reservation wage, $W_{r i}$ (Heckman 1974). The work decision is expressed as a simple probit:

$$
Y_{1 i}^{*}=\left(W_{m i}-W_{r i}\right)=\alpha_{0}+\alpha_{1} Z_{1 i}+v_{1 i}
$$

where $Y_{1 i}^{*}$ is an unobserved latent variable and $v_{1 \mathrm{i}} \sim \mathrm{N}\left(0, \sigma_{\mathrm{v} 1}^{2}\right) . \mathbf{Z}_{1 \mathrm{i}}$ contains exogenous socioeconomic and personal characteristics assumed to influence the relative values of $W_{m i}$ and $W_{r i}$ : age, gender, marital status, having children under the age of 18 , race, education, nonlabor and other household income, and controls for region of the country and Standard Metropolitan Statistical Areas (SMSA). The socioeconomic and human capital variables are interacted with gender to capture any potential gender differences. For example, it is expected that married men and men with children would be more likely to participate in the work force as these variables are indicators of fiscal responsibility. For women these same characteristics have traditionally been viewed as an indicator of an increased value of nonmarket time and thus negatively related to the work decision (Bowen and Finegan 1969).

It is expected that individuals with greater amounts of human capital will be more likely to participate in the labor force. Higher education, in general, leads to a higher reward for market work and, therefore, a higher cost for nonmarket activities (Rees 1979). Interacting education with gender allows for the determination of whether these returns differ between women and men. 
In addition to participation, the individual must also consider which occupation will be utility-maximizing. The worker may enter either a FD occupation or a NFD occupation, which is dependent not only on the choice of the individual but also on the hiring choices of employers. ${ }^{5}$ If the characteristics of NFD occupations are not appealing then the individual may be willing to give up money wages in order to enter into a FD occupation. Likewise, if characteristics of the individual are not appealing to employers of NFD occupations, the choices of the individual may be limited.

It is assumed that an individual will only enter a FD occupation if there is a net gain from doing so. If the wage an individual could expect to earn is lower in FD occupations relative to NFD occupations, then the individual would only enter a FD occupation if the wage penalty for doing so is less than the value of the nonwage characteristics of the FD occupation, $\mathrm{D}_{1}^{6}$. Thus, an individual who expects to earn lower wages in a FD occupation, is assumed to enter a FD occupation if :

$$
\left|\frac{W_{F D i}-W_{N F D i}}{W_{N F D i}}\right|<\rho_{i},
$$

where $\mathrm{W}_{\mathrm{NFDi}}$ and $\mathrm{W}_{\mathrm{FDi}}$ are the NFD and FD wages for the individual $i$.

More specifically, the individual's willingness to enter a FD occupation is expressed as:

$$
\rho_{i}=\beta_{0} Z_{2 i}+\beta_{1} C_{2 i}+\epsilon_{1 i}
$$


The vector of individual characteristics is $\mathbf{Z}_{2 \mathrm{i}}$ and $\mathbf{C}_{2 \mathrm{i}}$ is a vector representing the nonpecuniary benefits of entering a FD occupation, many of which are not observable. Therefore, $\mathbf{C}_{2 \mathrm{i}}$ is modeled using an unobservable variables approach, which assumes that the benefits of entering a FD occupation for the individual $I$ is a function of the observable individual characteristics plus an unobservable residual.

$$
\mathrm{C}_{2 \mathrm{i}}=\gamma_{0}+\gamma_{1} \mathbf{Z}_{2 \mathrm{i}}+\varepsilon_{2 \mathrm{i}}
$$

Substituting Equations (7) and (8) into Equation (6) indicates that the individual will enter into a FD occupation if :

$$
\left|\frac{W_{F D i}-W_{N F D i}}{W_{N F D i}}\right|<\left(\mathrm{B}_{0}+\mathrm{B}_{i} \gamma_{1}\right) \mathrm{Z}_{2 i}+\mathrm{B}_{1} \gamma_{0}+\mathrm{B}_{1} \varepsilon_{2 i}+\varepsilon_{1 i}
$$

Equation (9) indicates that there need not be a zero cost of choosing a FD occupation, just that the net benefit be greater than zero. This may be written in the form of a probit:

$$
Y_{2 i}^{*}=\delta_{0}+\delta_{1}\left(\frac{W_{F D i}-W_{N F D i}}{W_{N F D i}}\right)+\delta_{2} Z_{2 i}+\boldsymbol{V}_{2 i}
$$

The vector $\mathbf{Z}_{2 \mathrm{i}}$ contains observable exogenous socioeconomic and personal characteristics related to occupational choice: age, gender, marital status, race, education, other family labor income, and other forms of unearned income. ${ }^{7}$ In addition, the expected wage penalty for working in a FD occupation is included. Equation (9) predicts that individuals will enter FD occupations only if the value of the nonpecuniary benefits of working in a FD occupation are greater then the wage penalty for doing so. This implies that a decrease in the wage penalty, or an increase in the 
return to working in FD occupations relative to NFD occupations, will lower the cost of FD job characteristics and increase the likelihood that an individual will enter a FD occupation. Therefore, it is expected that the sign on the wage penalty will be positive. However, if there is no significant effect of the wage penalty on the occupational decision this implies the individual would enter a FD occupation regardless of the monetary cost. Assuming the job characteristics associated with typically female occupations are a normal good, this would violate rational economic behavior. Therefore, an insignificant result would lend support for the theory of discriminatory hiring practices by employers as an explanation for occupational segregation.

The human capital and socioeconomic variables are once again interacted with gender to determine if there are gender differences in both the labor demand and labor supply sides of the hiring market. For obvious reasons, it is expected that women will be more likely to enter FD occupations. If Polachek's (1981) theory holds, thus implying that FD occupations require less investment in human capital or requires skills that have a lower atrophy rate, then workers with high levels of education would be less likely to enter FD occupations. If job characteristics associated with the FD occupation are normal goods, then as income increases, there would be an increase in demand for these characteristics, resulting in a positive relationship between unearned and other household income and the decision to enter a FD occupation.

As shown in Equation (11), there are separate wage equations for workers in FD occupation and workers in NFD occupations, which allows for the full interaction between the gender distribution of an occupation and the independent variables in the wage equation. The 
vector $\mathbf{Z}_{3 \mathrm{i}}$ contains the socioeconomic and demographic characteristics age, gender, marital status, race, and level of education. The vector $\mathrm{O}_{2 \mathrm{i}}$ contains the characteristics of the job: current job tenure, part-time status, being a government worker, being represented by a labor union, nonpecuniary compensation such as a pension, employer sponsored group health insurance, and disability benefits, and controls for industry, SMSA, and regional differences.

$$
\begin{aligned}
& \log \mathrm{W}_{\mathrm{FDi}}=\phi_{0}+\phi_{1} \mathrm{Z}_{3 \mathrm{i}}+\phi_{2} \mathrm{X}_{2 \mathrm{i}}+\mathrm{v}_{3 \mathrm{i}} \\
& \log \mathrm{W}_{\mathrm{NFDi}}=\omega_{0}+\omega_{1} \mathrm{Z}_{3 \mathrm{i}}+\omega_{2} \mathrm{X}_{2 \mathrm{i}}+v_{4 \mathrm{i}} .
\end{aligned}
$$

The dependant variable of interest in the wage equations is the natural log of the wage. This allows for a simplification in the equation for the occupational choice of $\left(\log \mathrm{W}_{\mathrm{FDi}}\right.$ $\left.\log \mathrm{W}_{\text {NFDi }}\right)$, which is approximately equal to $\frac{\mathrm{W}_{\text {FDi }}-\mathrm{W}_{\text {NFDi }}}{\mathrm{W}_{\text {NFDi }}}$ (Lee 1979).

\section{DATA}

The data are taken from the May 1979 and the April 1993 supplements to the Current Population Surveys (CPS), a nationally representative survey that includes information on an individual's demographic and human capital characteristics as well as information on the worker's employee benefits in the previous year.

The 1980 and 1990 Public Use Microdata Samples (PUMS) are used to estimate the gender distribution of the detailed occupational categories in the U.S. Labor Force for the years 
1980 and 1990 as the cell size in the CPS is not large enough within the detailed 3-digit occupations to allow for statistical analysis. ${ }^{8}$ The occupational categories determined by the 1980 PUMS are then merged with the 1979 CPS and the 1990 PUMS are merged with the 1993 CPS. ${ }^{9}$

The detailed occupational categories are labeled female-dominated (FD) or nonfemaledominated (NFD), depending upon the percentage of females in the occupation. The methods previously used to define the gender classification of an occupation are varied. Beller (1982), when estimating the probability of entering a male occupation, calculates the female share of the labor force and adds five percentage points to reach the minimum percentage of females for a female-dominated occupation and subtracts five percentage points to reach the maximum percentage of females in a male-dominated occupation. Sorenson $(1989,1990)$ and Blau and Beller (1988) use a threshold of greater than 60 percent female to be considered a femaledominated occupation.

These methods may be problematic because the criteria for determining the type of the occupation is arbitrary. This research employs an inference test to determine if the distribution of the occupation is statistically different from the distribution of the labor force. If all occupations are perfectly integrated by gender, then all occupations would be distributed the same as the labor force. ${ }^{10}$ If the percent female in a 3-digit occupation is statistically higher than the percent female in the labor force then the occupation is labeled female-dominated (FD). If the percent female is statistically lower than the percent female in the labor force or there was no statistical difference, the occupation is labeled nonfemale-dominated (NFD). ${ }^{11}$ 
The distributions of occupations, as shown in Table 1, indicates that 32.3 percent of the occupations are classified as FD in 1980 and 35 percent in 1990. The distribution of males and females by occupation is presented in Table 2. Approximately 78.13 percent of women entered FD occupations in 1980 and 76 percent did so in 1990, indicating a slight decrease.

The full sample means and the means for workers taken from the CPS are presented in Table 3. There is information on 31,497 individuals in the 1979 sample and 36, 440 individuals in the 1993 sample. Of these, 51 percent in 1979 and 53 percent in 1993 are working. The percentage of the full sample that is married decreased from 67 percent in 1979 to 57 percent in 1993. The 1993 sample has a higher educational attainment as the percentage of the sample with some college is nine percentage points higher in 1993 and the percentage with less than a high school education is ten percentage points lower. In addition, the percentage of the sample that is of Hispanic origin is two and one-half percentage points greater in 1993.

For the workers, the biggest difference is the percentage of the labor force that is female. In 1979 females constituted 43 percent of the work force. This percentage increased to 51 percent in the 1993 sample. Again, the 1993 sample has a higher level of educational attainment, fewer married individuals, and a larger percentage of individuals of Hispanic origin. Fewer workers are represented by a union, a greater number work part-time, and fewer have pension plans.

Table 4 contains sample means stratified by occupation. The percentage female in FD occupations declined from 76 percent in 1979 to 72 percent in 1993. The real hourly wage in 
NFD occupations is $\$ 3.67$ per hour higher than the wage in FD occupations in 1979 and $\$ 1.86$ higher in 1993, thus indicating a decline in the wage differential over this period.

One interesting differential between occupational groups arises with respect to education. More workers in FD occupations have some college education and a smaller portion have less than a high school diploma when compared to workers in NFD occupations. There are more part-time and more government workers in FD occupations than in NFD occupations. However, workers in NFD occupations are more likely to be represented by a union and to have nonpecuniary benefits such as pension, disability, and health insurance.

\section{ESTIMATION}

The theoretical model gives rise to a system of equations that can be solved given a functional form for the utility function. However, the statistical model has to accommodate the conditional outcomes of observable data. In this case, the conditional outcome is that the individual's wage in an occupation is observed only if the individual chooses to participate in the labor force in that occupation. Therefore, the statistical model has to account for three situations: (1) the endogeneity of the occupation decision to the work decision; (2) the selection bias associated with observing only the wages of individuals who work; and (3) the selection bias associated with observing an individual's wage in an occupation only if the individual chooses to work in that occupation. ${ }^{12}$

The first stage of estimation is a bivariate probit with qualitative dependant variables of Work and $F D$, which controls for only observing the occupational choice of those who work. 
These results are the first stage in the sample selection model that is used to estimate the log wage regression for each of the occupational categories. The occupation decision is a reduced form estimation in which the wage equations are substituted for the wage penalty variable in the $F D$ equation. This results in a typical bivariate probit model with sample selection:

$$
\begin{aligned}
& Y_{1 i}^{*}=\alpha_{0}+\alpha_{1} \mathrm{Z}_{1 i}+v_{i 1} ; \\
& Y_{2 i}^{*}=\delta_{0}+\Omega_{1} \mathrm{X}_{2 i}+\delta_{2} \mathrm{Z}_{i}+v_{2 i} ; \\
& {\left[v_{1 i}, v_{2 i}\right] \sim B V N[0,0,1,1, \rho]}
\end{aligned}
$$

where $\mathbf{Z}_{\mathrm{i}}$ includes all characteristics of the individual; $\mathbf{X}_{2 \mathrm{i}}$ includes the observed characteristics of the job; $\mathbf{S}$ is a vector of $*, \mathbf{N}$, and $\mathbf{f}$; and $Y_{1 i}^{*}$ and $Y_{2 i}^{*}$ are unobserved latent variables. Observed in the data is the outcome of the work and the occupational choice decisions, with the latter being a function of the relationship described in Equation (9).

As shown in Equation (13), if $Y_{1}^{*}$ is less than zero, there is a net loss to working and the individual will not work. However, if $Y_{1}^{*}$ is greater than or equal to 0 there is a net benefit to working and the individual will work. Likewise, if $Y_{2}^{*}$ is less than zero, there is a net loss to working and the individual will not work. If $Y_{2}^{*}$ is greater than or equal to 0 there is a net benefit to working and the individual will work. The caveat arises in that while Work $_{i}$ is always observed, $F D_{i}$ is observed if, and only if, Work $_{i}$ is equal to one. Therefore, if the individual 
decides not to work we do not observe the occupation they would have chosen.

$$
\begin{aligned}
& \text { Work }_{i}=1 \text { if } Y_{1 i}^{*} \geq 0 ; \text { Work }_{i}=0 \text { if } Y_{1 i}^{*}<0 ; \\
& \text { if } Y_{1 i}^{*} \geq 0 \text { then: } \\
& F D_{i}=1 \text { if } Y_{\vartheta_{i}}^{*} \geq 0 ; F D_{i}=0 \text { if } Y_{\eta_{i}}^{*}<0 .
\end{aligned}
$$

There is a separate wage estimation performed for individuals in FD occupations and individuals in NFD occupations, with sample selection used to control for the biases of observing the wage only in the chosen occupation of individuals who have chosen to work.

$$
\begin{aligned}
& \log _{\text {FDi }}=\phi_{0}+\phi_{1} z_{3 i}+\phi_{2} X_{2 i}+d_{1} \lambda_{1 i}+d_{2} \lambda_{2 i}+v_{3 i} ; \\
& \log _{N F D i}=\omega_{0}+\omega_{1} z_{3 i}+\omega_{2} X_{2 i}+d_{3} \lambda_{3 i}+d_{4} \lambda_{4 i}+v_{4 i}
\end{aligned}
$$

The selection terms associated with the occupational decision are $8_{1 \mathrm{i}}$ and $8_{3 \mathrm{i}}$ while the selection terms associated with the decision to work are $8_{2 \mathrm{i}}$ and $8_{4 \mathrm{i}}$. It is expected that individuals will enter the occupation for which there will be greater returns and that individuals with greater labor market potential will enter the labor force. Therefore, the expected signs on the selection coefficients are positive for $d_{2}, d_{4}$, and $d_{1}$ and negative for $d_{3}$. Once the wage penalty has been estimated, it is substituted into the FD equation and the bivariate probit is reestimated with a structural model for FD. 


\section{RESULTS}

\section{A. Wage Equations}

The first stage results, presented in Table 5, indicate that women are penalized relative to the men in their occupation no matter which occupation they choose. However, they are penalized to a lesser degree in the FD occupations. ${ }^{13}$ Although the coefficient on female is positive across all four wage estimations, and significant in the FD estimation for both years, the total effect of being female, evaluated at the sample means and considering the interaction terms, is negative.

Age, education, marital status and job tenure all interact with female to determine if there are gender differentials in the return to human capital and/or socioeconomic characteristics explaining the overall gender wage differential. The most consistent difference arises from the return to age. In general, it is expected that earnings will increase at a decreasing rate with age. However, there is a negative and significant coefficient on the interaction terms between female and both age and age-squared. There is still an overall positive return to another year of age for a female but it is much smaller than for men and the peak is reached at an earlier age. In fact, at the sample means, females are experiencing a negative return for an additional year of age while men are receiving a positive return. As there is no measure of general work experience available in the data set, the variable may be picking up some of the return to market experience, which is, in general, expected to be higher for men than women because of the previously discussed intermittent participation and nonmarket commitments. 
There is a positive return to being married for both men and women, albeit a much smaller one for women, in both occupations in 1993 and in FD occupations in 1979. Married women in NFD occupations in 1979 face a marriage penalty while the men face a premium. Although there is no statistical difference in the return to a high school education between men and women in 1993, women in NFD occupations receive a greater return than men for some college education and men in FD occupations in 1993 receive a great return than women to some college education. There is no statistical gender difference in the return to tenure at current job, except in the NFD occupations in 1979 where women see a greater return than men for an extra year of tenure.

For the base case of a single female with a high school education working in a FD occupation, evaluated at the female sample means for age and years of job tenure, the expected wage is 11 percent lower than a male would expect in 1979 and six percent lower in 1993. For the NFD occupations, the differences are much larger: 32 percent less in 1979 and 35 percent less in 1993. As mentioned earlier, a large part of this negative effect is attributed to age. At an age of 25 , females are estimated to earn only 2 percentage points less than males in the 1979 FD occupations. In 1993 there is a positive return to being female for this age group, with females expecting seven percent higher wages than the males in FD occupations. However by age 33, any positive affect for being female had disappeared.

There is also a negative effect for being female in NFD occupations, regardless of age or survey year, with the differential increasing with age. This relative advantage for the younger 
cohorts of women could be due to relatively better opportunities for younger cohorts of women and/or less variation in entry level jobs in general.

The receipt of employer sponsored pension plans, disability, and health insurance benefits are associated with higher wages for all categories. This is not unexpected as the value of these benefits are greater for the high wage worker (Rosen, 2000). ${ }^{14}$ However, the effect is much higher in NFD occupations than in FD occupations. One possible explanation for the different magnitudes could be that workers in FD occupations are willing to give up more wages to receive these benefits than workers in NFD occupations.

The other results are as expected, with blacks and individuals of Hispanic origin facing a wage penalty. However, it is interesting to note that the wage penalty is larger in FD than in NFD occupations, and the magnitude of the coefficient on black increases over the time period. This does not support Cain's (1986) theory that the unexplained wage differentials are "vintage effects" from the precivil rights discrimination and should diminish over time. In addition, the effect of working part-time is negative, as expected, due to lower level of attachment to the labor force (Hotchkiss 1991).

\section{B. Wage Penalty}

The second stage wage equations are used to estimate the FD wage penalty, $\log \mathrm{W}_{\mathrm{FDi}}$ $\log \mathrm{W}_{\mathrm{NFDi}}$, each worker would receive for working in a FD occupation compared to a NFD occupation. This is the expected wage penalty variable that is included in the structural model. These wage penalties are summarized in Tables 6 and 7. The results differ greatly by survey 
year, by gender, and by chosen occupation. Contrary to expectations, there is not a FD wage penalty for all individuals in the sample, rather some individuals earned a FD wage premium. On average, female workers in 1979 would expect to earn nine percent higher wages for entering a FD occupation relative to a NFD occupation. For the females who choose to work in FD occupations, the average benefit to working in a FD occupation is eleven percent. However, as expected, there is an average FD wage penalty for all males in 1979, although the penalty is lower for the males who choose to work in FD occupations.

In 1993 there is an overall average FD wage penalty of half of a percentage point for females, although there is a benefit, albeit very small, for working in FD occupations for the women who choose to do so. As expected, there is a FD wage penalty for males working in a FD occupation, but, once again, the penalty is lower for the males who choose to enter FD occupations.

There is a significant difference in the wage penalty between the two survey years. While the women who choose to work in FD occupations in 1993 still face a slight FD wage premium, the value decreased by approximately 11 percent. This could indicate that these workers are investing more in human capital characteristics that are more appealing to employers in NFD occupations or that the characteristics associated with workers in typically female occupations are becoming more valuable in NFD occupations. ${ }^{15}$

As shown in Figure 1, age plays a large role in determining the wage penalty and it differs greatly between the two survey years. For female workers in FD occupations in 1979 
there is a clear increase in the FD wage premium with age, which appears to be driven by a relative decrease in value in NFD occupations rather than an increasing value in FD occupations. No age group has an average FD wage penalty, thus indicating that the characteristics of these workers are not as valuable in NFD occupations. By 1993, the distribution for the female workers in FD occupations had changed dramatically. Younger and older women face a FD wage premium, but women in their thirties and forties face a very slight FD wage penalty. Once again, the increase in the FD wage premium for older workers appears to be driven by a relative decrease in the expected wage in NFD occupations rather than an increase in expected wage in the FD occupations.

Overall, the wage premium for working in FD occupations in both years is not just attributable to lower expected wages than their counterparts in the NFD occupations but also to relatively higher expected wages in FD occupations. For example, women working in FD occupations in 1979 have a 20 cent higher expected hourly wage in FD occupations than the women working in NFD occupations but a 20 cent lower expected wage in the NFD occupations. This indicates that there exists sorting that is resulting in a relatively better return on skills in FD occupations for the workers that choose FD occupations.

These results mitigate the ability of occupational crowding to explain the wage differential. While it is true that workers in FD occupations earn, on average, less than workers in NFD occupations, the wage differential would not decrease by significant amounts or could actually increase in some circumstances if the workers in FD occupations switched to NFD 
occupations.

\section{Work and Occupational Choice}

The estimation results for the structural occupational choice and labor supply model are reported in Table 8 . The dominant explanatory variable in both years is the wage differential, $\log \mathrm{W}_{\mathrm{FDi}}-\log \mathrm{W}_{\mathrm{NFDi}}$, or the wage penalty for working in a FD occupation. The sign on this variable is positive, indicating that, ceteris paribus, a positive benefit for working in a FD occupation results in a higher probability of entering a FD occupation. This suggests that individuals enter the occupation that provides the greatest monetary reward and does not support the theory that there are discriminatory hiring practices preventing women from entering certain occupations in this time period.

Workers with some college education are more likely to enter FD occupations than workers with a high school diploma or less, with no statistical difference between genders. Married women also have a higher probability of entering a FD occupation. An increase in other household income increases the probability of choosing a FD occupation as does living in an SMSA. Blacks and workers of Hispanic origin are less likely to be working in a FD occupation.

For the work decision, the results are as expected. The probability of working increases at a decreasing rate with age, although the interaction of female with age has a negative coefficient. Women are more likely to work than men although this probability decreases for married women and women with kids. Finally, more education increases the probability of 
working while increasing the level of other income lowers the probability.

The correlation coefficient between the occupation and the work decisions is not significant in the structural model in either year but is significant in the reduced form model in 1979. Therefore, the results seem to indicate that unbiased estimates of occupational choice could be estimated independently of the work decision, especially with more recent data. This implies that workers do not have a higher probability of entering one occupation or the other when compared to nonworkers (Sorenson 1990).

\section{Selection Bias}

The selection coefficient for occupational choice in the FD wage equation, $d_{1}$, is positive and significant for the FD wage equation for both years, indicating that workers in FD occupations expect to earn a higher wage in that occupation than workers in NFD occupations. The occupational selection coefficient in the NFD wage equation, $d_{3}$, is negative although only significant in 1979. This indicates that the workers in NFD occupations would expect to earn higher wages in NFD occupations than workers who choose FD occupations. The selection coefficients for the work decision, $\mathrm{d}_{2}$ and $\mathrm{d}_{4}$, are positive, and significant for all categories except FD in 1979, indicating that those who choose to work have a higher earnings potential than those who do not.

In order to better understand the impact of the selection biases accounted for in the previous estimation, a wage equation is estimated for workers in each occupation that did not control for any selection bias. These equations are used to compute wage differentials that are 
comparable to earlier research. However, the outcomes are drastically different than in the selection models.

Under this methodology there is a penalty for entering a FD occupation, which is the opposite of what is found in the selection model. The penalty for working in FD occupations is higher for females than males and is higher for workers in FD occupations over workers in NFD occupations. Thus, the noncorrected results overstate the occupational wage differential facing women but understate the occupational wage differential facing men. Treating the endogenous work and occupational choice decisions as exogenous would predict that workers in FD occupations would earn higher wages in NFD, thus erroneously indicating that occupational segregation is at least partially responsible for the wage differentials between genders, as has been found the earlier literature.

\section{CONCLUSION}

The primary question addressed in this article is why workers would enter an occupation where the expected wage is less. For women working in FD occupations, the answer is that they can expect wages that are similar or even greater in FD occupations as compared to NFD occupations. In other words, there is a wage premium for women associated with choosing to work in FD occupations. Thus, occupational segregation theory is not likely to be the explanation for the wage differential between genders. If occupational segregation is the primary cause of the gender wage differential, then the women working in FD occupations should be able to earn higher wages in NFD occupations - something which is not supported by 
this research. The results presented here differ from the earlier literature because the selection bias inherent in the decision to work and the decision of what occupation to work in are explicitly incorporated into the analysis. When models are estimated ignoring these effects, the results are similar to those in the past are found, which support occupational segregation as the cause of the gender wage differential. However, the selection model results support McPherson and Hirsch (1995), who suggest policies designed to alter women's occupational choices will not impact the gender wage differential, since a large percentage of women are as well, or better off, in FD occupations as compared to NFD occupations.

An additional result of this research is that the occupational wage differential reduces the probability that women will enter a FD occupation. In other words, while women who do choose to work in FD occupations do so because they are better off than in NFD, if the wage differential between FD and NFD occupations increases, fewer women will continue to choose FD occupations. Because the wage-differential between these occupations (the "cost" of choosing a FD occupation) is an important predictor of occupational choice, I again suggest there is little support for the occupational crowding model Had the wage-differential been found not significant, it would indicate workers are not taking into account the relative costs of their occupational choice and would have lent support for discriminatory hiring practices causing workers to not enter occupations with the highest return. However, as the magnitude is quite large, these results seem to support that there are gender differences in human capital, tastes, and/or preferences that result in the self-selection of individuals into different occupations. This 
research leaves unanswered why the characteristics of workers in FD occupations appear to be less valuable in the labor force relative to the characteristics of workers in NFD occupations -discrimination may be a possible explanation.

Lastly, while this research suggests that FD occupations are preferable market outcomes for many women, there is still a persistent unexplained wage-differential associated with being female regardless of whether the occupational choice is FD or NFD. In FD occupations, women are estimated to earn 11 percent less than men in 1979 and six percent less in 1993. For NFD occupations, the differences are much larger and persistent over time: women earned 32 percent less than men in 1979 and 35 percent less in 1993. Once again, discrimination cannot be ruled out as a possible explanation. 
Table 1

Distributions of Occupations

by Year

\begin{tabular}{lcc}
\hline \hline Occupation & 1980 & 1990 \\
\hline \hline $\begin{array}{l}\text { Nonfemale- } \\
\text { Dominated }\end{array}$ & $67.7 \%$ & $65.0 \%$ \\
Female-Dominated & $32.3 \%$ & $35.0 \%$ \\
\hline \hline
\end{tabular}

Table 2

Distributions of Workers

by Occupation

\begin{tabular}{clccc}
\hline \hline Year & Occupation & All & Males & Females \\
\hline \hline \multirow{2}{*}{1980} & $\begin{array}{l}\text { Nonfemale- } \\
\text { Dominated } \\
\text { Female- }\end{array}$ & 55.06 & 81.99 & 21.87 \\
& $\begin{array}{l}\text { Dominated } \\
\text { Domfemale- }\end{array}$ & 52.91 & 78.63 & 23.60 \\
& $\begin{array}{l}\text { Nonfer } \\
\text { Dominated } \\
\text { Female- }\end{array}$ & 47.09 & 21.37 & 76.40 \\
& $\begin{array}{l}\text { Femaled } \\
\text { Dominated }\end{array}$ & & & \\
\hline \hline
\end{tabular}


Table 3

Sample Means

(std. dev.)

\begin{tabular}{lcccc}
\hline \hline & \multicolumn{2}{c}{ Full Sample } & \multicolumn{2}{c}{ Workers } \\
\hline \hline Variable & 1979 & 1993 & 1979 & 1993 \\
\hline \hline Individual Characteristics & & & & \\
Age & 45.6533 & 46.1395 & 39.4993 & 37.9649 \\
& $(19.0585)$ & $(19.7448)$ & $(13.3672)$ & $(12.4145)$ \\
Married & 0.6684 & 0.5674 & 0.7267 & 0.6044 \\
& $(0.4708)$ & $(0.4954)$ & $(0.4457)$ & $(0.4890)$ \\
Female & 0.5756 & 0.5781 & 0.4266 & 0.5102 \\
& $(0.4943)$ & $(0.4939)$ & $(0.4946)$ & $(0.4999)$ \\
Black & 0.0990 & 0.0924 & 0.0895 & 0.0819 \\
& $(0.2987)$ & $(0.2896)$ & $(0.2855)$ & $(0.2743)$ \\
Hispanic Origin & 0.0435 & 0.0668 & 0.0416 & 0.0662 \\
& $(0.2039)$ & $(0.2496)$ & $(0.1997)$ & $(0.2487)$ \\
No High School Diploma & 0.3596 & 0.2559 & 0.2094 & 0.1296 \\
& $(0.4799)$ & $(0.4364)$ & $(0.4069)$ & $(0.3359)$ \\
High School Diploma & 0.3293 & 0.3392 & 0.3808 & 0.3484 \\
& $(0.4700)$ & $(0.4734)$ & $(0.4856)$ & $(0.4765)$ \\
Some College Education & 0.3111 & 0.4049 & 0.4098 & 0.5220 \\
& $(0.4630)$ & $(0.4909)$ & $(0.4918)$ & $(0.4995)$ \\
Work & 0.5105 & 0.5342 & & \\
Job Characteristics & $(0.4999)$ & $(0.4988)$ & & \\
Female- Dominated & & & & \\
Occupation & & & 0.3978 & 0.5791 \\
Hourly Wage & & & $(0.4895)$ & $(0.4945)$ \\
(1993 \$) & & & $(7.7994)$ & $(8.0538)$ \\
\hline \hline
\end{tabular}


Table 3 (cont.)

\begin{tabular}{|c|c|c|c|c|}
\hline \multirow[b]{2}{*}{ Variable } & \multicolumn{2}{|c|}{ Full Sample } & \multicolumn{2}{|c|}{ Workers } \\
\hline & 1979 & 1993 & 1979 & 1993 \\
\hline Current Job Tenure & & & $\begin{array}{c}8.6808 \\
(8.3318)\end{array}$ & $\begin{array}{c}7.0964 \\
(7.7773)\end{array}$ \\
\hline Government Employee & & & $\begin{array}{c}0.2212 \\
(0.4150)\end{array}$ & $\begin{array}{c}0.1827 \\
(0.3864)\end{array}$ \\
\hline Part-time Employee & & & $\begin{array}{c}0.1298 \\
(0.3361)\end{array}$ & $\begin{array}{c}0.2024 \\
(0.4018)\end{array}$ \\
\hline Represented by a Union & & & $\begin{array}{c}0.3366 \\
(0.4726)\end{array}$ & $\begin{array}{c}0.1870 \\
(0.3899)\end{array}$ \\
\hline $\begin{array}{l}\text { Employer-Sponsored } \\
\text { Pension Plan }\end{array}$ & & & $\begin{array}{c}0.6044 \\
(0.4890)\end{array}$ & $\begin{array}{c}0.4772 \\
(0.4995)\end{array}$ \\
\hline $\begin{array}{l}\text { Employer-Sponsored } \\
\text { Disability Benefits }\end{array}$ & & & $\begin{array}{c}0.3981 \\
(0.4895)\end{array}$ & $\begin{array}{c}0.3937 \\
(0.4886)\end{array}$ \\
\hline $\begin{array}{l}\text { Employer-Sponsored Health } \\
\text { Insurance }\end{array}$ & & & $\begin{array}{c}0.7475 \\
(0.4345)\end{array}$ & $\begin{array}{c}0.7881 \\
(0.4087)\end{array}$ \\
\hline \multicolumn{5}{|l|}{ Household Characteristics } \\
\hline $\begin{array}{l}\text { Children Under the Age of } \\
18\end{array}$ & $\begin{array}{c}0.4334 \\
(0.4956)\end{array}$ & $\begin{array}{c}0.3488 \\
(0.4766)\end{array}$ & $\begin{array}{c}0.4908 \\
(0.4999)\end{array}$ & $\begin{array}{c}0.4381 \\
(0.4962)\end{array}$ \\
\hline $\begin{array}{l}\text { Other Household Income } \\
(\$ 10,000)(1993 \$)\end{array}$ & $\begin{array}{c}2.0580 \\
(2.2856)\end{array}$ & $\begin{array}{l}2.4590 \\
(2.7057)\end{array}$ & $\begin{array}{c}1.8327 \\
(14.1718)\end{array}$ & $\begin{array}{c}2.2657 \\
(2.4975)\end{array}$ \\
\hline Northeast Region & $\begin{array}{c}0.2329 \\
(0.4227)\end{array}$ & $\begin{array}{c}0.2381 \\
(0.4259)\end{array}$ & $\begin{array}{c}0.2303 \\
(0.4210)\end{array}$ & $\begin{array}{c}0.2278 \\
(0.4195)\end{array}$ \\
\hline Midwest Region & $\begin{array}{c}0.2612 \\
(0.4393)\end{array}$ & $\begin{array}{c}0.2509 \\
(0.4335)\end{array}$ & $\begin{array}{c}0.2720 \\
(0.4450)\end{array}$ & $\begin{array}{c}0.2611 \\
(0.4393)\end{array}$ \\
\hline West Region & $\begin{array}{c}0.2986 \\
(0.4576)\end{array}$ & $\begin{array}{c}0.3020 \\
(0.4591)\end{array}$ & $\begin{array}{c}0.2873 \\
(0.4525)\end{array}$ & $\begin{array}{c}0.2966 \\
(0.4568)\end{array}$ \\
\hline Southern Region & $\begin{array}{c}0.2073 \\
(0.4054)\end{array}$ & $\begin{array}{c}0.2091 \\
(0.4066)\end{array}$ & $\begin{array}{c}0.2105 \\
(0.4076)\end{array}$ & $\begin{array}{c}0.2144 \\
(0.4104)\end{array}$ \\
\hline
\end{tabular}


Table 3 (cont.)

\begin{tabular}{lcccc}
\hline \hline & \multicolumn{2}{c}{ Full Sample } & \multicolumn{2}{c}{ Workers } \\
\hline \hline Variable & 1979 & 1993 & 1979 & 1993 \\
\hline \hline SMSA & 0.5933 & 0.5473 & 0.6098 & 0.5480 \\
& $(0.4912)$ & $(0.4978)$ & $(0.4878)$ & $(0.4977)$ \\
$\mathrm{n}$ & 31497 & 36440 & 16079 & 19465 \\
\hline \hline
\end{tabular}


Table 4

Sample Means by Occupation

(std. dev.)

\begin{tabular}{|c|c|c|c|c|}
\hline & \multicolumn{2}{|c|}{1979} & \multicolumn{2}{|c|}{1993} \\
\hline Variable & NED & $\mathrm{ED}$ & NED & $\overline{\mathrm{ED}}$ \\
\hline \multicolumn{5}{|l|}{ Individual Characteristics } \\
\hline Age & $\begin{array}{c}39.7225 \\
(13.2268\end{array}$ & $\begin{array}{c}39.1615 \\
(13.5711\end{array}$ & $\begin{array}{c}38.0411 \\
(11.8526\end{array}$ & $\begin{array}{c}37.9084 \\
(12.8157\end{array}$ \\
\hline Married & $\begin{array}{c}0.7637 \\
(0.4248)\end{array}$ & $\begin{array}{c}0.6706 \\
(0.4700)\end{array}$ & $\begin{array}{c}0.6440 \\
(0.4788)\end{array}$ & $\begin{array}{c}0.5749 \\
(0.4944)\end{array}$ \\
\hline Female & $\begin{array}{c}0.2036 \\
(0.4027)\end{array}$ & $\begin{array}{c}0.7642 \\
(0.4245)\end{array}$ & $\begin{array}{c}0.2280 \\
(0.4196)\end{array}$ & $\begin{array}{c}0.7196 \\
(0.4492)\end{array}$ \\
\hline Black & $\begin{array}{c}0.0872 \\
(0.2821)\end{array}$ & $\begin{array}{c}0.0930 \\
(0.2905)\end{array}$ & $\begin{array}{c}0.0752 \\
(0.2637)\end{array}$ & $\begin{array}{c}0.0870 \\
(0.2818)\end{array}$ \\
\hline Hispanic Origin & $\begin{array}{c}0.0485 \\
(0.2149)\end{array}$ & $\begin{array}{c}0.0311 \\
(0.1736)\end{array}$ & $\begin{array}{c}0.0706 \\
(0.2561)\end{array}$ & $\begin{array}{c}0.0630 \\
(0.2430)\end{array}$ \\
\hline No High School Diploma & $\begin{array}{c}0.2544 \\
(0.4355)\end{array}$ & $\begin{array}{c}0.1413 \\
(0.3484)\end{array}$ & $\begin{array}{c}0.1560 \\
(0.3628)\end{array}$ & $\begin{array}{c}0.1101 \\
(0.3130)\end{array}$ \\
\hline High School Diploma & $\begin{array}{c}0.3774 \\
(0.4848)\end{array}$ & $\begin{array}{c}0.3860 \\
(0.4869)\end{array}$ & $\begin{array}{c}0.3918 \\
(0.4882)\end{array}$ & $\begin{array}{c}0.3162 \\
(0.4650)\end{array}$ \\
\hline Some College Education & $\begin{array}{c}0.3683 \\
(0.4824)\end{array}$ & $\begin{array}{c}0.4726 \\
(0.4993)\end{array}$ & $\begin{array}{c}0.4522 \\
(0.4977)\end{array}$ & $\begin{array}{c}0.5737 \\
(0.4946)\end{array}$ \\
\hline \multicolumn{5}{|l|}{ Job Characteristics } \\
\hline $\begin{array}{l}\text { Hourly Wage } \\
(1993 \$)\end{array}$ & $\begin{array}{l}15.6348 \\
(8.2783)\end{array}$ & $\begin{array}{l}11.9568 \\
(6.4059)\end{array}$ & $\begin{array}{l}12.6594 \\
(9.0761)\end{array}$ & $\begin{array}{c}10.7959 \\
(7.0994)\end{array}$ \\
\hline Current Job Tenure & $\begin{array}{c}9.3997 \\
(8.7955)\end{array}$ & $\begin{array}{c}7.5926 \\
(7.4458)\end{array}$ & $\begin{array}{c}7.7818 \\
(8.2712)\end{array}$ & $\begin{array}{c}6.5879 \\
(7.3488)\end{array}$ \\
\hline Government Employee & $\begin{array}{c}0.1689 \\
(0.3746)\end{array}$ & $\begin{array}{c}0.3003 \\
(0.4584)\end{array}$ & $\begin{array}{c}0.1228 \\
(0.3282)\end{array}$ & $\begin{array}{c}0.2271 \\
(0.4190)\end{array}$ \\
\hline
\end{tabular}


Table 4 (cont.)

\begin{tabular}{|c|c|c|c|c|}
\hline & \multicolumn{2}{|c|}{1979} & \multicolumn{2}{|c|}{1993} \\
\hline & NFD & FD & NFD & FD \\
\hline \multicolumn{5}{|l|}{ Job Characteristics } \\
\hline Part-time Employee & $\begin{array}{c}0.0761 \\
(0.2652)\end{array}$ & $\begin{array}{c}0.2111 \\
(0.4081)\end{array}$ & $\begin{array}{c}0.1086 \\
(0.3111)\end{array}$ & $\begin{array}{c}0.2719 \\
(0.4450)\end{array}$ \\
\hline Represented by a Union & $\begin{array}{c}0.3758 \\
(0.4844)\end{array}$ & $\begin{array}{c}0.2772 \\
(0.4477)\end{array}$ & $\begin{array}{c}0.2136 \\
(0.4099)\end{array}$ & $\begin{array}{c}0.1672 \\
(0.3732)\end{array}$ \\
\hline $\begin{array}{l}\text { Employ e r - S p o n s o r ed } \\
\text { Pension Plan }\end{array}$ & $\begin{array}{c}0.6418 \\
(0.4795)\end{array}$ & $\begin{array}{c}0.5477 \\
(0.4978)\end{array}$ & $\begin{array}{c}0.5099 \\
(0.4999)\end{array}$ & $\begin{array}{c}0.4529 \\
(0.4978)\end{array}$ \\
\hline $\begin{array}{l}\text { Employ er - S p o n s or ed } \\
\text { Disability Benefits }\end{array}$ & $\begin{array}{c}0.4490 \\
(0.4974)\end{array}$ & $\begin{array}{c}0.3210 \\
(0.4669)\end{array}$ & $\begin{array}{c}0.4392 \\
(0.4963)\end{array}$ & $\begin{array}{c}0.3600 \\
(0.4800)\end{array}$ \\
\hline $\begin{array}{l}\text { Employer-Sponsored Health } \\
\text { Insurance }\end{array}$ & $\begin{array}{c}0.8017 \\
(0.3987)\end{array}$ & $\begin{array}{c}0.6654 \\
(0.4719)\end{array}$ & $\begin{array}{c}0.8084 \\
(0.3935)\end{array}$ & $\begin{array}{c}0.7730 \\
(0.4189)\end{array}$ \\
\hline $\begin{array}{l}\text { Household Characteristics } \\
\text { Other Household Income } \\
(\$ 10,000)(1993 \$)\end{array}$ & $\begin{array}{c}1.5316 \\
(1.9623)\end{array}$ & $\begin{array}{c}2.2886 \\
(2.3888)\end{array}$ & $\begin{array}{c}1.9418 \\
(2.2946)\end{array}$ & $\begin{array}{l}2.5060 \\
(2.6122)\end{array}$ \\
\hline $\begin{array}{l}\text { Children Under the Age of } \\
18\end{array}$ & $\begin{array}{c}0.5100 \\
(0.4999)\end{array}$ & $\begin{array}{c}0.4619 \\
(0.4986)\end{array}$ & $\begin{array}{c}0.4435 \\
(0.4968)\end{array}$ & $\begin{array}{c}0.4340 \\
(0.4956)\end{array}$ \\
\hline Northeast Region & $\begin{array}{c}0.2243 \\
(0.4171)\end{array}$ & $\begin{array}{c}0.2394 \\
(0.4267)\end{array}$ & $\begin{array}{c}0.2142 \\
(0.4103)\end{array}$ & $\begin{array}{c}0.2379 \\
(0.4258)\end{array}$ \\
\hline Midwest Region & $\begin{array}{c}0.2753 \\
(0.4467)\end{array}$ & $\begin{array}{c}0.2669 \\
(0.4424)\end{array}$ & $\begin{array}{c}0.2688 \\
(0.4433)\end{array}$ & $\begin{array}{c}0.2555 \\
(0.4362)\end{array}$ \\
\hline West Region & $\begin{array}{c}0.2853 \\
(0.4516)\end{array}$ & $\begin{array}{c}0.2902 \\
(0.4539)\end{array}$ & $\begin{array}{c}0.3054 \\
(0.4606)\end{array}$ & $\begin{array}{c}0.2901 \\
(0.4538)\end{array}$ \\
\hline Southern Region & $\begin{array}{c}0.2150 \\
(0.4109)\end{array}$ & $\begin{array}{c}0.2036 \\
(0.4027)\end{array}$ & $\begin{array}{c}0.2116 \\
(0.4085)\end{array}$ & $\begin{array}{c}0.2165 \\
(0.4119)\end{array}$ \\
\hline SMSA & $\begin{array}{c}0.6016 \\
(0.4896)\end{array}$ & $\begin{array}{c}0.6223 \\
(0.4849)\end{array}$ & $\begin{array}{c}0.5276 \\
(0.4993)\end{array}$ & $\begin{array}{c}0.5630 \\
(0.4960)\end{array}$ \\
\hline $\mathrm{n}$ & 9683 & 6396 & 8290 & 11175 \\
\hline
\end{tabular}


Table $5^{1,2}$

Wage Equations

(standard error)

\begin{tabular}{|c|c|c|c|c|}
\hline & \multicolumn{2}{|c|}{1979} & \multicolumn{2}{|c|}{1993} \\
\hline Variable & $\overline{\mathrm{ED}}$ & $\overline{\mathrm{NFD}}$ & $\overline{\mathrm{ED}}$ & NFD \\
\hline Constant & $\begin{array}{l}0.9359 * * * \\
(0.1592)\end{array}$ & $\begin{array}{l}1.1717 * * * \\
(0.0795)\end{array}$ & $\begin{array}{l}0.3793 * * * \\
(0.1136)\end{array}$ & $\begin{array}{l}0.6167 * * * \\
(0.1278)\end{array}$ \\
\hline \multicolumn{5}{|l|}{ Individual } \\
\hline Age & $\begin{array}{l}0.0466^{* * *} \\
(0.0059)\end{array}$ & $\begin{array}{l}0.0473 * * * \\
(0.0040)\end{array}$ & $\begin{array}{l}0.0512 * * * \\
(0.0054)\end{array}$ & $\begin{array}{l}0.0515 * * * \\
(0.0057)\end{array}$ \\
\hline Age Squared & $\begin{array}{l}-0.0005 * * * \\
(0.0001)\end{array}$ & $\begin{array}{l}-0.0005 * * * \\
(0.0001)\end{array}$ & $\begin{array}{l}-0.0006 * * * \\
(0.0001)\end{array}$ & $\begin{array}{l}-0.0006 * * * \\
(0.0001)\end{array}$ \\
\hline Female & $\begin{array}{l}0.4120 * * * \\
(0.1407)\end{array}$ & $\begin{array}{l}0.0522 \\
(0.1245)\end{array}$ & $\begin{array}{l}0.3950 * * * \\
(0.0900)\end{array}$ & $\begin{array}{l}0.0437 \\
(0.1589)\end{array}$ \\
\hline Married & $\begin{array}{l}0.0918 * * * \\
(0.0252)\end{array}$ & $\begin{array}{l}0.0986 * * * \\
(0.0137)\end{array}$ & $\begin{array}{l}0.1141^{* * * *} \\
(0.0195)\end{array}$ & $\begin{array}{l}0.0905 * * * \\
(0.0161)\end{array}$ \\
\hline Black & $\begin{array}{l}-0.0732 * * * \\
(0.0176)\end{array}$ & $\begin{array}{l}-0.1221 * * * \\
(0.0146)\end{array}$ & $\begin{array}{l}-0.1292 * * * \\
(0.0151)\end{array}$ & $\begin{array}{l}-0.1872 * * * \\
(0.0189)\end{array}$ \\
\hline Hispanic Origin & $\begin{array}{l}-0.0909 * * * \\
(0.0271)\end{array}$ & $\begin{array}{l}-0.1389 * * * \\
(0.0184)\end{array}$ & $\begin{array}{l}-0.0879 * * * \\
(0.0164)\end{array}$ & $\begin{array}{l}-0.1612 * * * \\
(0.0192)\end{array}$ \\
\hline No High School Diploma & $\begin{array}{l}-0.2224 * * * \\
(0.0383)\end{array}$ & $\begin{array}{l}-0.1341 * * * \\
(0.0147)\end{array}$ & $\begin{array}{l}-0.1226 * * * \\
(0.0279)\end{array}$ & $\begin{array}{l}-0.1097 * * * \\
(0.0195)\end{array}$ \\
\hline Some College Education & $\begin{array}{l}0.1442 * * * \\
(0.0318)\end{array}$ & $\begin{array}{l}0.1599 * * * \\
(0.0118)\end{array}$ & $\begin{array}{l}0.3094 * * * \\
(0.0263)\end{array}$ & $\begin{array}{l}0.1695 * * * \\
(0.0175)\end{array}$ \\
\hline \multicolumn{5}{|l|}{ Job Characteristics } \\
\hline Current Job Tenure & $\begin{array}{l}0.0118 * * * \\
(0.0035)\end{array}$ & $\begin{array}{l}0.0057 * * * \\
(0.0017)\end{array}$ & $\begin{array}{l}0.0183 * * * \\
(0.0028)\end{array}$ & $\begin{array}{l}0.0140 * * * \\
(0.0019)\end{array}$ \\
\hline $\begin{array}{l}\text { Current Job Tenure } \\
\text { Squared }\end{array}$ & $\begin{array}{l}-0.0002 * * * \\
(0.0001)\end{array}$ & $\begin{array}{l}0.0000 \\
(0.0000)\end{array}$ & $\begin{array}{l}-0.0002 * * * \\
(0.0001)\end{array}$ & $\begin{array}{l}-0.0003 * * * \\
(0.0001)\end{array}$ \\
\hline Part-time Employee & $\begin{array}{l}-0.0458 * * * \\
(0.0139)\end{array}$ & $\begin{array}{l}-0.1058 * * * \\
(0.0169)\end{array}$ & $\begin{array}{l}-0.0630 * * * \\
(0.0107)\end{array}$ & $\begin{array}{l}-0.1191 * * * \\
(0.0190)\end{array}$ \\
\hline Represented by a Union & $\begin{array}{l}0.0449 * * * \\
(0.0124)\end{array}$ & $\begin{array}{l}0.0193 * * \\
(0.0090)\end{array}$ & $\begin{array}{l}0.0845 * * * \\
(0.0120)\end{array}$ & $\begin{array}{l}0.0527 * * * \\
(0.0124)\end{array}$ \\
\hline
\end{tabular}


Table 5 (cont.)

\begin{tabular}{|c|c|c|c|c|}
\hline \multirow{2}{*}{ Variable } & \multicolumn{2}{|c|}{1979} & \multicolumn{2}{|c|}{1993} \\
\hline & FD & NFD & FD & NFD \\
\hline \multicolumn{5}{|l|}{ Job Characteristics } \\
\hline Government Employee & $\begin{array}{l}0.0313 * \\
(0.0190)\end{array}$ & $\begin{array}{l}-0.1276 * * * \\
(0.0186)\end{array}$ & $\begin{array}{l}0.0171 \\
(0.0157)\end{array}$ & $\begin{array}{l}-0.1018 * * * \\
(0.0208)\end{array}$ \\
\hline $\begin{array}{l}\text { Employer-Sponsored } \\
\text { Pension Plan }\end{array}$ & $\begin{array}{l}0.0549 * * * \\
(0.0137)\end{array}$ & $\begin{array}{l}0.0812 * * * \\
(0.0120)\end{array}$ & $\begin{array}{l}0.1191 * * * \\
(0.0102)\end{array}$ & $\begin{array}{l}0.1771 * * * \\
(0.0118)\end{array}$ \\
\hline $\begin{array}{l}\text { Employer-Sponsored } \\
\text { Disability Benefits }\end{array}$ & $\begin{array}{l}0.0448 * * * \\
(0.0130)\end{array}$ & $\begin{array}{l}0.0875 * * * \\
(0.0106)\end{array}$ & $\begin{array}{l}0.0960 * * * \\
(0.0091)\end{array}$ & $\begin{array}{l}0.0919 * * * \\
(0.0104)\end{array}$ \\
\hline $\begin{array}{l}\text { Employer-Sponsored } \\
\text { Health Insurance }\end{array}$ & $\begin{array}{l}0.0802 * * * \\
(0.0123)\end{array}$ & $\begin{array}{l}0.1261 * * * \\
(0.0117)\end{array}$ & $\begin{array}{l}0.0700 * * * \\
(0.0110)\end{array}$ & $\begin{array}{l}0.1320 * * * \\
(0.0143)\end{array}$ \\
\hline \multicolumn{5}{|l|}{ Female Interaction } \\
\hline Age*Female & $\begin{array}{l}-0.0260 * * * \\
(0.0059)\end{array}$ & $\begin{array}{l}-0.0198 * * * \\
(0.0051)\end{array}$ & $\begin{array}{l}-0.0158 * * * \\
(0.0041)\end{array}$ & $\begin{array}{l}-0.0137 * * * \\
(0.0067)\end{array}$ \\
\hline Age Squared*Female & $\begin{array}{l}0.0003 * * * \\
(0.0001)\end{array}$ & $\begin{array}{l}0.0002 * * * \\
(0.0001)\end{array}$ & $\begin{array}{l}0.0001^{* * *} \\
(0.0000)\end{array}$ & $\begin{array}{l}0.0001 \\
(0.0001)\end{array}$ \\
\hline Married*Female & $\begin{array}{l}-0.0489 \\
(0.0306)\end{array}$ & $\begin{array}{l}-0.1329 * * * \\
(0.0282)\end{array}$ & $\begin{array}{l}-0.1061 * * * \\
(0.0251)\end{array}$ & $\begin{array}{l}-0.0500 * \\
(0.0307)\end{array}$ \\
\hline $\begin{array}{l}\text { No High School } \\
\text { Diploma*Female }\end{array}$ & $\begin{array}{l}0.0895 * * \\
(0.0381)\end{array}$ & $\begin{array}{l}0.0503 * \\
(0.0291)\end{array}$ & $\begin{array}{l}-0.0447 \\
(0.0318)\end{array}$ & $\begin{array}{l}-0.0404 \\
(0.0374)\end{array}$ \\
\hline $\begin{array}{l}\text { Some College } \\
\text { Education*Female }\end{array}$ & $\begin{array}{l}0.0276 \\
(0.0343)\end{array}$ & $\begin{array}{l}0.0747 * * * \\
(0.0233)\end{array}$ & $\begin{array}{l}-0.0609 * * \\
(0.0284)\end{array}$ & $\begin{array}{l}0.1317 * * * \\
(0.0261)\end{array}$ \\
\hline $\begin{array}{l}\text { Current Job } \\
\text { Tenure*Female }\end{array}$ & $\begin{array}{l}0.0038 \\
(0.0041)\end{array}$ & $\begin{array}{l}0.0179 * * * \\
(0.0038)\end{array}$ & $\begin{array}{l}0.0005 \\
(0.0032)\end{array}$ & $\begin{array}{l}-0.0024 \\
(0.0043)\end{array}$ \\
\hline $\begin{array}{l}\text { Current Job Tenure } \\
\text { Squared*Female }\end{array}$ & $\begin{array}{l}0.0001 \\
(0.0001)\end{array}$ & $\begin{array}{l}-0.0005 * * * \\
(0.0001)\end{array}$ & $\begin{array}{l}0.0000 \\
(0.0001)\end{array}$ & $\begin{array}{l}0.0001 \\
(0.0002)\end{array}$ \\
\hline \multicolumn{5}{|l|}{ Household } \\
\hline Northeast Region & $\begin{array}{l}0.0299 * * \\
(0.0130)\end{array}$ & $\begin{array}{l}-0.0320 * * * \\
(0.0108)\end{array}$ & $\begin{array}{l}0.1020 * * * \\
(0.0110)\end{array}$ & $\begin{array}{l}0.0940 * * * \\
(0.0135)\end{array}$ \\
\hline West Region & $\begin{array}{l}-0.0137 \\
(0.0129)\end{array}$ & $\begin{array}{l}-0.0540 * * * \\
(0.0105)\end{array}$ & $\begin{array}{l}0.0088 \\
(0.0103)\end{array}$ & $\begin{array}{l}0.0113 \\
(0.0122)\end{array}$ \\
\hline
\end{tabular}


Table 5 (cont.)

\begin{tabular}{|c|c|c|c|c|}
\hline & \multicolumn{2}{|c|}{1979} & \multicolumn{2}{|c|}{1993} \\
\hline Variable & FD & NFD & FD & NFD \\
\hline \multicolumn{5}{|l|}{ Household } \\
\hline Southern Region & $\begin{array}{l}0.0683 * * * \\
(0.0141)\end{array}$ & $\begin{array}{l}0.0837 * * * \\
(0.0115)\end{array}$ & $\begin{array}{l}0.0786^{* * *} \\
(0.0113)\end{array}$ & $\begin{array}{l}0.1111 * * * \\
(0.0137)\end{array}$ \\
\hline SMSA & $\begin{array}{l}0.1110 * * * \\
(0.0100)\end{array}$ & $\begin{array}{l}0.0989 * * * \\
(0.0083)\end{array}$ & $\begin{array}{l}0.1435 * * * \\
(0.0080)\end{array}$ & $\begin{array}{l}0.1322 * * * \\
(0.0097)\end{array}$ \\
\hline \multicolumn{5}{|c|}{ Selection Variables } \\
\hline $8_{1}$ & $\begin{array}{l}0.1623 * * \\
(0.0717)\end{array}$ & & $\begin{array}{l}0.2037 * * * \\
(0.0701)\end{array}$ & \\
\hline $8_{2}$ & $\begin{array}{l}0.0143 \\
(0.0308)\end{array}$ & & $\begin{array}{l}0.1439 * * * \\
(0.0379)\end{array}$ & \\
\hline $8_{3}$ & & $\begin{array}{l}-0.1277 * \\
(0.0668)\end{array}$ & & $\begin{array}{l}-0.1034 \\
(0.0783)\end{array}$ \\
\hline $8_{4}$ & & $\begin{array}{l}0.0768 * * \\
(0.0321)\end{array}$ & & $\begin{array}{l}0.1125^{* *} \\
(0.0509)\end{array}$ \\
\hline $\mathrm{R}^{2}$ & 0.4435 & 0.4650 & 0.5043 & 0.4701 \\
\hline
\end{tabular}

$1 *$ significant at the $10 \%$ level; ** significant at the $5 \%$ level; $* * *$ significant at the $1 \%$ level.

${ }^{2} 22$ industry dummy variables are included in the estimation. These results are available from the author upon request. 
Table 6

FD Wage Premium

$\left(\log \mathrm{W}_{\mathrm{FDi}}-\log \mathrm{W}_{\mathrm{NFDi}}\right)$

(percentage)

\begin{tabular}{|c|c|c|c|c|c|c|c|c|c|}
\hline \multirow{3}{*}{$\begin{array}{c}\text { Gender } \\
\\
\text { Year }\end{array}$} & \multirow[t]{3}{*}{ Occ } & \multicolumn{2}{|c|}{ All } & \multicolumn{6}{|c|}{ Level of Education } \\
\hline & & & & \multicolumn{2}{|c|}{$\begin{array}{c}\text { No HS } \\
\text { Diploma }\end{array}$} & \multicolumn{2}{|c|}{ HS diploma } & \multicolumn{2}{|c|}{ Some College } \\
\hline & & 79 & 93 & 79 & 93 & 79 & 93 & 79 & 93 \\
\hline \multirow[t]{2}{*}{ Female } & FD & 11.24 & 0.28 & 9.97 & 5.40 & 10.04 & 2.54 & 12.90 & -2.13 \\
\hline & NFD & 2.50 & -3.88 & 3.77 & 1.35 & 4.46 & -1.84 & -1.62 & -6.92 \\
\hline \multirow[t]{2}{*}{ Male } & FD & -14.76 & $\begin{array}{c}- \\
1530\end{array}$ & -26.81 & -20.74 & -21.54 & -23.68 & -9.99 & -11.21 \\
\hline & NFD & -27.06 & $\begin{array}{c}- \\
24.23\end{array}$ & -29.90 & -29.49 & 25.71 & -30.73 & -26.52 & -16.52 \\
\hline
\end{tabular}

Table 7

FD Wage Premium

$\left(\log \mathrm{W}_{\mathrm{FDi}}-\log \mathrm{W}_{\mathrm{NFDi}}\right)$

(percentage)

\begin{tabular}{l|l|cc|c|c|c|c}
\hline \hline Gender & Occupation & \multicolumn{6}{c|}{ Race } \\
& & \multicolumn{2}{|c|}{ White } & \multicolumn{2}{c|}{ Black } & \multicolumn{2}{c}{ Hispanic Origin } \\
\hline \hline \multirow{2}{*}{ Year } & & 79 & 93 & 79 & 93 & 79 & 93 \\
\hline \hline \multirow{2}{*}{ Females } & FD & 10.41 & -0.49 & 18.86 & 8.13 & 9.05 & 1.05 \\
& NFD & 1.38 & -4.21 & 9.69 & 0.56 & 3.29 & -5.47 \\
& FD & -15.26 & -15.67 & -7.55 & -10.44 & -16.03 & -22.46 \\
& NFD & -27.65 & -24.72 & -20.24 & -18.74 & -26.78 & -25.62 \\
\hline \hline
\end{tabular}


Table $8^{1}$

Bivariate Probit

Structural Model

(standard errors)

\begin{tabular}{|c|c|c|c|c|}
\hline & \multicolumn{2}{|c|}{1979} & \multicolumn{2}{|c|}{1993} \\
\hline Variable & $\overline{\mathrm{ED}}$ & Work & $\overline{\mathrm{ED}}$ & Work \\
\hline Constant & $\begin{array}{l}-0.8008 * * * \\
(0.2277)\end{array}$ & $\begin{array}{l}-2.5850 * * * \\
(0.1157)\end{array}$ & $\begin{array}{l}0.5221 * * \\
(0.2547)\end{array}$ & $\begin{array}{l}-1.9179 * * * \\
(0.0966)\end{array}$ \\
\hline $\begin{array}{l}\text { NFD Wage Premium } \\
\left(\log W_{F D i}-\log W_{\text {NFDi }}\right)\end{array}$ & $\begin{array}{l}2.4419^{* * *} \\
(0.0800)\end{array}$ & & $\begin{array}{l}2.3686 * * * \\
(0.0792)\end{array}$ & \\
\hline \multicolumn{5}{|l|}{ Individual Characteristics } \\
\hline Age & $\begin{array}{l}0.0134 \\
(1.1455)\end{array}$ & $\begin{array}{l}21.5769 * * * \\
(0.5470)\end{array}$ & $\begin{array}{l}-0.0272 * * \\
(0.0129)\end{array}$ & $\begin{array}{l}0.1767 * * * \\
(0.0043)\end{array}$ \\
\hline Age Squared & $\begin{array}{l}-0.0002 \\
(0.0001)\end{array}$ & $\begin{array}{l}-0.0003 * * * \\
(0.0001)\end{array}$ & $\begin{array}{l}0.0002 * \\
() 0.0002\end{array}$ & $\begin{array}{l}-0.0024^{* * *} \\
(0.0000)\end{array}$ \\
\hline Female & $\begin{array}{l}1.3354 * * * \\
(0.2184)\end{array}$ & $\begin{array}{l}0.9390 * * \\
(0.1394)\end{array}$ & $\begin{array}{l}1.0622 * * * \\
(0.1948)\end{array}$ & $\begin{array}{l}0.4035 * * * \\
(0.1218)\end{array}$ \\
\hline Married & $\begin{array}{l}-0.0455 \\
(0.0470)\end{array}$ & $\begin{array}{l}0.7161 \\
(0.0418)\end{array}$ & $\begin{array}{l}-0.2200 * * * \\
(0.0388)\end{array}$ & $\begin{array}{l}0.5754 * * * \\
(0.0350)\end{array}$ \\
\hline Black & $\begin{array}{l}-0.2843 * * * \\
(0.0429)\end{array}$ & $\begin{array}{l}-0.0630 \\
(0.0285)\end{array}$ & $\begin{array}{l}-0.1033 * * * \\
(0.0417)\end{array}$ & $\begin{array}{l}-0.3094 * * * \\
(0.0282)\end{array}$ \\
\hline Hispanic Origin & $\begin{array}{l}-0.2756^{* * *} \\
(0.0625)\end{array}$ & $\begin{array}{l}-0.0787 * * * \\
(0.0428)\end{array}$ & $\begin{array}{l}-0.0755^{*} \\
(0.0429)\end{array}$ & $\begin{array}{l}-0.1250^{* * *} \\
(0.0321)\end{array}$ \\
\hline No High School Diploma & $\begin{array}{l}-0.0983 * \\
(0.0541)\end{array}$ & $\begin{array}{l}-0.6247 * * * \\
(0.0384)\end{array}$ & $\begin{array}{l}0.0187 \\
(0.0556)\end{array}$ & $\begin{array}{l}-0.5232 * * * \\
(0.0352)\end{array}$ \\
\hline Some College Education & $\begin{array}{l}0.3913^{* * *} \\
(0.0387)\end{array}$ & $\begin{array}{l}-0.0739 * \\
(0.0425)\end{array}$ & $\begin{array}{l}0.2253 * * * \\
(0.0334)\end{array}$ & $\begin{array}{l}0.1035 * * * \\
(0.0330)\end{array}$ \\
\hline \multicolumn{5}{|l|}{ Female Interaction Terms } \\
\hline Age*Female & $\begin{array}{l}-0.0129 \\
(0.0113)\end{array}$ & $\begin{array}{l}-0.0648 * * * \\
(0.0068)\end{array}$ & $\begin{array}{l}-0.0237 * * * \\
(0.0099)\end{array}$ & $\begin{array}{l}-0.0308^{* * *} \\
(0.0057)\end{array}$ \\
\hline Age Squared*Female & $\begin{array}{l}0.0001 \\
(0.0001)\end{array}$ & $\begin{array}{l}0.0008 * * * \\
(0.0001)\end{array}$ & $\begin{array}{l}0.0003 * * * \\
(0.0001)\end{array}$ & $\begin{array}{l}0.0004 * * * \\
(0.0001)\end{array}$ \\
\hline
\end{tabular}


Table 8 (cont.)

\begin{tabular}{|c|c|c|c|c|}
\hline & \multicolumn{2}{|c|}{1979} & \multicolumn{2}{|c|}{1993} \\
\hline Variable & $\overline{\mathrm{ED}}$ & Work & $\overline{\mathrm{ED}}$ & Work \\
\hline \multicolumn{5}{|l|}{ Female Interaction Terms } \\
\hline Married*Female & $\begin{array}{l}-0.1591^{* *} \\
(0.0705)\end{array}$ & $\begin{array}{l}-1.1714 * \\
(0.0494)\end{array}$ & $\begin{array}{l}0.3706^{* * *} \\
(0.0597)\end{array}$ & $\begin{array}{l}-0.8150 * * * \\
(0.0422)\end{array}$ \\
\hline $\begin{array}{l}\text { Children Under the Age of } \\
18^{*} \text { Female }\end{array}$ & & $\begin{array}{l}-0.5271 * * * \\
(0.0452)\end{array}$ & & $\begin{array}{l}-0.2780 * * * \\
(0.0422)\end{array}$ \\
\hline $\begin{array}{l}\text { No High School } \\
\text { Diploma*Female }\end{array}$ & $\begin{array}{l}-0.2627 * * * \\
(0.0671)\end{array}$ & $\begin{array}{l}0.1304 * * * \\
(0.0464)\end{array}$ & $\begin{array}{l}-0.2504 * * * \\
(0.0700)\end{array}$ & $\begin{array}{l}-0.0446 \\
(0.0450)\end{array}$ \\
\hline $\begin{array}{l}\text { Some College } \\
\text { Education*Female }\end{array}$ & $\begin{array}{l}-0.1819 * * * \\
(0.0555)\end{array}$ & $\begin{array}{l}0.2211 * * * \\
(0.0497)\end{array}$ & $\begin{array}{l}0.0180 \\
(0.0494)\end{array}$ & $\begin{array}{l}0.1853 * * * \\
(0.0404)\end{array}$ \\
\hline \multicolumn{5}{|l|}{ Household } \\
\hline $\begin{array}{l}\text { Children Under the Age of } \\
18\end{array}$ & & $\begin{array}{l}-0.0466 \\
(0.0376)\end{array}$ & & $\begin{array}{l}0.0006 \\
(0.0346)\end{array}$ \\
\hline $\begin{array}{l}\text { Other Household Income } \\
(\$ 10,000)(1993 \$)\end{array}$ & $\begin{array}{l}0.0129 * * \\
(0.0562)\end{array}$ & $\begin{array}{l}-0.2842 * * * \\
(0.0366)\end{array}$ & $\begin{array}{l}0.0012 * * * \\
(0.0004)\end{array}$ & $\begin{array}{l}-0.0041^{* * *} \\
(0.0003)\end{array}$ \\
\hline Northeast Region & $\begin{array}{l}-0.0936 * * * \\
(0.0340)\end{array}$ & $\begin{array}{l}-0.0828 * * * \\
(0.0250)\end{array}$ & $\begin{array}{l}0.0585^{* *} \\
(0.0295)\end{array}$ & $\begin{array}{l}-0.1214 * * * \\
(0.0234)\end{array}$ \\
\hline West Region & $\begin{array}{l}-0.0183 \\
(0.0326)\end{array}$ & $\begin{array}{l}-0.1090 * * * \\
(0.0237)\end{array}$ & $\begin{array}{l}0.0347 \\
(0.0279)\end{array}$ & $\begin{array}{l}-0.0477 * * \\
(0.0225)\end{array}$ \\
\hline Southern Region & $\begin{array}{l}-0.0389 \\
(0.0353)\end{array}$ & $\begin{array}{l}-0.1600 * * * \\
(0.0260)\end{array}$ & $\begin{array}{l}0.1193 * * * \\
(0.0305)\end{array}$ & $\begin{array}{l}-0.1338 * * * \\
(0.0244)\end{array}$ \\
\hline SMSA & $\begin{array}{l}0.0542 * * \\
(0.0249)\end{array}$ & $\begin{array}{l}-0.0030 \\
(0.0183)\end{array}$ & $\begin{array}{l}0.0390 * \\
(0.0210)\end{array}$ & $\begin{array}{l}-0.0305 * \\
(0.0169)\end{array}$ \\
\hline Correlation Coefficient & $\begin{array}{l}0.1240 \\
(0.0814)\end{array}$ & & $\begin{array}{l}0.0755 \\
(0.1107)\end{array}$ & \\
\hline
\end{tabular}

$1 *$ significant at the $10 \%$ level; ** significant at the $5 \%$ level; *** significant at the $1 \%$ level. 
Figne 1

Fenales inFDCcapations

FDWage Prenimby Age

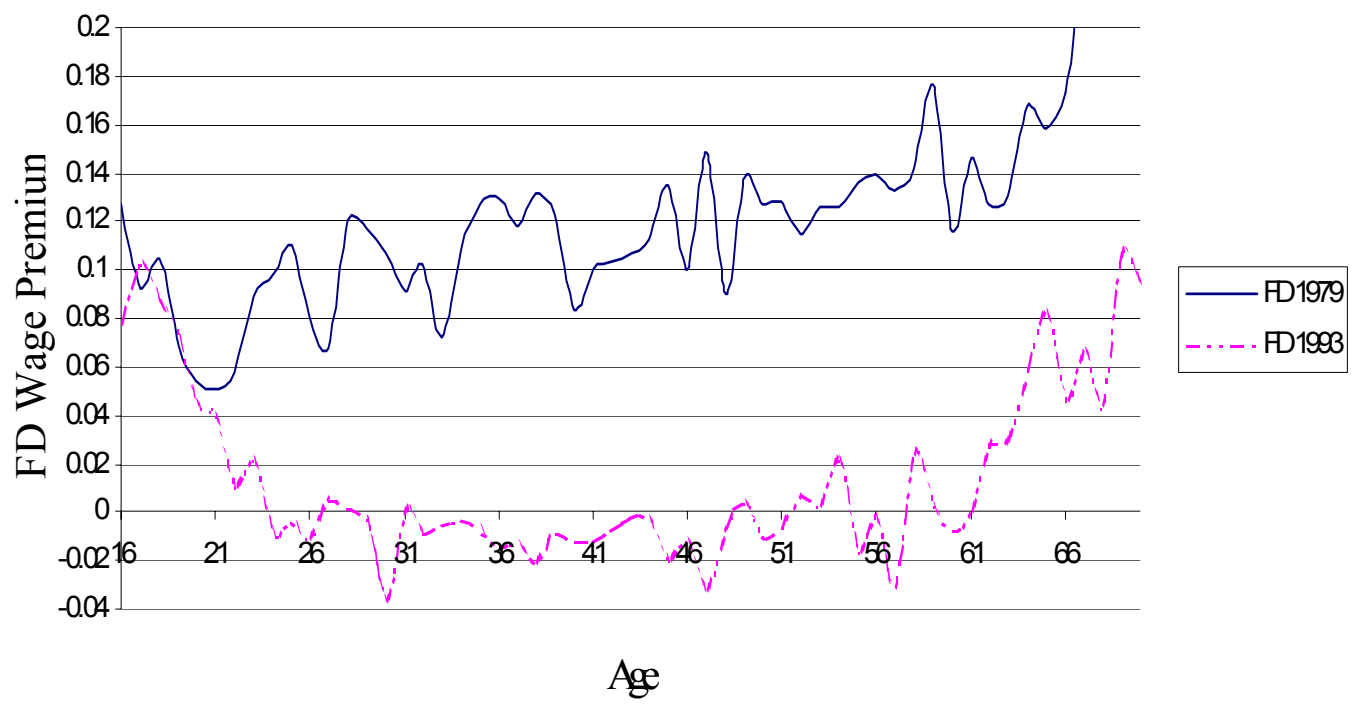




\section{APPENDIX}

Bivariate Probit ${ }^{1}$

Reduced Form

(standard error)

\begin{tabular}{|c|c|c|c|c|}
\hline \multirow{2}{*}{ Variable } & \multicolumn{2}{|c|}{1979} & \multicolumn{2}{|c|}{1993} \\
\hline & FD & NFD & FD & NFD \\
\hline Constant & $\begin{array}{l}-1.2000 * * * \\
(0.2369)\end{array}$ & $\begin{array}{l}-2.5850 * * * \\
(0.1159)\end{array}$ & $\begin{array}{l}0.0209 \\
(0.2818)\end{array}$ & $\begin{array}{l}-1.9142 * * * \\
(0.0965)\end{array}$ \\
\hline \multicolumn{5}{|l|}{ Individual } \\
\hline Age & $\begin{array}{l}0.0178 \\
(0.0123)\end{array}$ & $\begin{array}{l}0.0216 * * * \\
(0.0055)\end{array}$ & $\begin{array}{l}-0.0172 \\
(0.0144)\end{array}$ & $\begin{array}{l}0.1766^{* * * *} \\
(0.0043)\end{array}$ \\
\hline Age Squared & $\begin{array}{l}-0.0002 \\
(0.0001)\end{array}$ & $\begin{array}{l}-0.0028 * * * \\
(0.0001)\end{array}$ & $\begin{array}{l}0.0002 \\
(0.0002)\end{array}$ & $\begin{array}{l}-0.0024 * * * \\
(0.0000)\end{array}$ \\
\hline Female & $\begin{array}{l}2.1280 * * * \\
(0.2338)\end{array}$ & $\begin{array}{l}0.9389 * * * \\
(0.1396)\end{array}$ & $\begin{array}{l}1.8939 * * * \\
(0.2098)\end{array}$ & $\begin{array}{l}0.4001 * * * \\
(0.1218)\end{array}$ \\
\hline Married & $\begin{array}{l}-0.0445 \\
(0.0482)\end{array}$ & $\begin{array}{l}0.7164 * * * \\
(0.0419)\end{array}$ & $\begin{array}{l}-0.1517 * * * \\
(0.0411)\end{array}$ & $\begin{array}{l}0.5753 * * * \\
(0.0350)\end{array}$ \\
\hline Black & $\begin{array}{l}-0.1473 * * * \\
(0.0447\end{array}$ & $\begin{array}{l}-0.0619 * * \\
(0.0285)\end{array}$ & $\begin{array}{l}0.0528 \\
(0.0449-)\end{array}$ & $\begin{array}{l}-0.3092 * * * \\
(0.0282)\end{array}$ \\
\hline Hispanic Origin & $\begin{array}{l}-0.0942 \\
(0.0653)\end{array}$ & $\begin{array}{l}-0.0788 * \\
(0.0428)\end{array}$ & $\begin{array}{l}0.1008 * * \\
(0.0459)\end{array}$ & $\begin{array}{l}-0.1256^{* * *} \\
(0.0321)\end{array}$ \\
\hline $\begin{array}{l}\text { No High School } \\
\text { Diploma }\end{array}$ & $\begin{array}{l}-0.3010 * * * \\
(0.0555)\end{array}$ & $\begin{array}{l}-0.6246 * * * \\
(0.0384)\end{array}$ & $\begin{array}{l}0.0296 \\
(0.0623)\end{array}$ & $\begin{array}{l}0.5231 * * * \\
(0.0352)\end{array}$ \\
\hline $\begin{array}{l}\text { Some College } \\
\text { Education }\end{array}$ & $\begin{array}{l}0.2691 * * * \\
(0.0402)\end{array}$ & $\begin{array}{l}-0.0740 * \\
(0.0425)\end{array}$ & $\begin{array}{l}0.3979 * * * \\
(0.0344)\end{array}$ & $\begin{array}{l}0.1028 * * * \\
(0.0330)\end{array}$ \\
\hline $\begin{array}{l}\text { No High School } \\
\text { Diploma*Female }\end{array}$ & $\begin{array}{l}-0.1961 * * * \\
(0.0697)\end{array}$ & $\begin{array}{l}0.1302 * * * \\
(0.0465)\end{array}$ & $\begin{array}{l}-0.2369 * * * \\
(0.0783)\end{array}$ & $\begin{array}{l}-0.0449 \\
(0.0450)\end{array}$ \\
\hline $\begin{array}{l}\text { Some College } \\
\text { Education*Female }\end{array}$ & $\begin{array}{l}-0.2480 * * * \\
(0.0566)\end{array}$ & $\begin{array}{l}0.2209 * * * \\
(0.0497)\end{array}$ & $\begin{array}{l}-0.3957 * * * \\
(0.0493)\end{array}$ & $\begin{array}{l}0.1861 * * * \\
(0.0404)\end{array}$ \\
\hline
\end{tabular}


Appendix (cont.)

\begin{tabular}{|c|c|c|c|c|}
\hline & \multicolumn{2}{|c|}{1979} & \multicolumn{2}{|c|}{1993} \\
\hline$\overline{\text { Variable }}$ & $\overline{\mathrm{FD}}$ & NED & $\overline{\mathrm{FD}}$ & "NFD \\
\hline \multicolumn{5}{|c|}{ Job } \\
\hline Current Job Tenure & $\begin{array}{l}0.2011 \\
(0.0063)\end{array}$ & & $\begin{array}{l}-0.0048 \\
(0.0055)\end{array}$ & \\
\hline $\begin{array}{l}\text { Current Job Tenure } \\
\text { Squared }\end{array}$ & $\begin{array}{l}0.4601 \\
(0.0002)\end{array}$ & & $\begin{array}{l}0.0001 \\
(0.0016)\end{array}$ & \\
\hline $\begin{array}{l}\text { Part-time } \\
\text { Employee }\end{array}$ & $\begin{array}{l}0.1186^{* * * *} \\
(0.0406)\end{array}$ & & $\begin{array}{l}0.1795 * * * \\
(0.0325)\end{array}$ & \\
\hline $\begin{array}{l}\text { Represented by a } \\
\text { Union }\end{array}$ & $\begin{array}{l}-0.0689^{* *} \\
(0.0298)\end{array}$ & & $\begin{array}{l}-0.0646^{* *} \\
(0.0334)\end{array}$ & \\
\hline $\begin{array}{l}\text { Government } \\
\text { Employee }\end{array}$ & $\begin{array}{l}0.2097 * * * \\
(0.0509)\end{array}$ & & $\begin{array}{l}0.0326 \\
(0.0460)\end{array}$ & \\
\hline $\begin{array}{l}\text { Employer- } \\
\text { Sponsored Pension }\end{array}$ & $\begin{array}{l}-0.0021 \\
(0.0370)\end{array}$ & & $\begin{array}{l}0.0156 \\
(0.0282)\end{array}$ & \\
\hline $\begin{array}{l}\text { Employer- } \\
\text { Sponsored }\end{array}$ & $\begin{array}{l}-0.0752^{* *} \\
(0.0339)\end{array}$ & & $\begin{array}{l}-0.0237 \\
(0.0252)\end{array}$ & \\
\hline $\begin{array}{l}\text { Employer- } \\
\text { Sponsored Health }\end{array}$ & $\begin{array}{l}-0.0104 \\
(0.0337)\end{array}$ & & $\begin{array}{l}-0.0957^{* * *} \\
(0.0325)\end{array}$ & \\
\hline \multicolumn{5}{|l|}{$\begin{array}{l}\text { Female } \\
\text { Interaction Terms }\end{array}$} \\
\hline Age*Female & $\begin{array}{l}-3.5130^{* * *} \\
(0.0125)\end{array}$ & $\begin{array}{l}-0.0648 * * * \\
(0.0068)\end{array}$ & $\begin{array}{l}-0.0360 \text { *** } \\
(0.01107\end{array}$ & \\
\hline $\begin{array}{l}\text { Age } \\
\text { Squared*Female }\end{array}$ & $\begin{array}{l}0.0004 * * * \\
(0.0001)\end{array}$ & $\begin{array}{l}0.0008^{* * *} \\
(0.0001)\end{array}$ & $\begin{array}{l}0.0004 * * * \\
(0.0001)\end{array}$ & $\begin{array}{l}0.0004 * * * \\
(0.0001)\end{array}$ \\
\hline Married*Female & $\begin{array}{l}0.0349 \\
(0.0719)\end{array}$ & $\begin{array}{l}-1.1716^{* * *} \\
(0.0495)\end{array}$ & $\begin{array}{l}0.2089^{* * *} \\
(0.0625)\end{array}$ & $\begin{array}{l}-0.8155^{* * *} \\
(0.0422)\end{array}$ \\
\hline $\begin{array}{l}\text { Children Under the } \\
\text { Age of } 18 * \text { Female }\end{array}$ & & $\begin{array}{l}-0.5273 * * * \\
(0.0452)\end{array}$ & & $\begin{array}{l}-0.2767^{* * *} \\
(0.0422)\end{array}$ \\
\hline $\begin{array}{l}\text { Current Job } \\
\text { Tenure*Female }\end{array}$ & $\begin{array}{l}0.005111 \\
(0.9388)\end{array}$ & & $\begin{array}{l}0.0045 \\
(0.0082)\end{array}$ & \\
\hline $\begin{array}{l}\text { Current Job Tenure } \\
\text { Squared*Female }\end{array}$ & $\begin{array}{l}-0.0008 \\
(0.0000)\end{array}$ & & $\begin{array}{l}0.0000 \\
(0.0003)\end{array}$ & \\
\hline
\end{tabular}




\begin{tabular}{lllll}
\multicolumn{5}{c}{ Appendix (cont.) } \\
\hline \hline Variable & \multicolumn{2}{c}{1979} & \multicolumn{1}{c}{1993} \\
\hline Household & & & & \\
Other Household & 0.0091 & $0.0284 * * *$ & 0.0005 & $-0.0041^{* * *}$ \\
Income & $(0.0058)$ & $(0.0037)$ & $(0.0004)$ & $(0.0003)$ \\
Children Under the & & -0.0468 & & 0.0015 \\
Age of 18 & & $(0.0375)$ & & $(0.0346)$ \\
Northeast Region & 0.0383 & $-0.0831 * * *$ & $0.0648 * *$ & $-0.1219 * * *$ \\
& $(0.0344)$ & $(0.0250)$ & $(0.0310)$ & $(0.0234)$ \\
West Region & 0.0429 & $-0.1091 * * *$ & -0.0023 & $-0.0479 * *$ \\
& $(0.0338)$ & $(0.0237)$ & $(0.0293)$ & $(0.0225)$ \\
Southern Region & $-0.0665 *$ & $-0.1601 * * *$ & 0.0207 & $-0.1337 * * *$ \\
& $(0.0361)$ & $(0.0260)$ & $(0.0322)$ & $(0.0245)$ \\
SMSA & $0.0655^{* * *}$ & -0.0031 & $0.0605 * * *$ & $-0.0303 *$ \\
& $(0.0258)$ & $(0.0183)$ & $(0.0223)$ & $(0.0169)$ \\
Correlation & $0.1635^{* *}$ & & -1.5780 & \\
Coefficient & $(0.0845)$ & & $(0.1359)$ & \\
\hline \hline
\end{tabular}

$1 *$ significant at the $10 \%$ level; $* *$ significant at the $5 \%$ level; $* * *$ significant at the $1 \%$ level. 


\section{NOTES}

1. The authors refer to these limitations as "societal discrimination".

2. For a full explanation of the theoretical model, see Pitts and McDermed (1994).

3. Examples of nonpecuniary job characteristics include levels of explicit fringe benefits such as pensions and health insurance and inexplicit benefits such as levels of safety, degree of time flexibility, and status. This analysis holds constant the quality of the matching of the individual's abilities and human capital with the skill requirements of the job.

4. For simplicity, the price of a job characteristic is assumed to be independent of hours of work.

5. This empirical model follows the framework developed by Lee (1978) to examine the decision to enter a labor union.

6. $\mathrm{D}_{1}$ can take on a positive or a negative value.

7. The variable indicating the presence of children under the age of 18 is used to identify the work equation. In previous estimations, the coefficient on this variable in the occupational choice estimation was insignificant and removing the variable from the model did not affect the results.

8. The PUMS is a stratified sample consisting of a subsample of the housing units that received the 1980 or 1990 Census of Public Housing "long form" questionnaire and consists of approximately 16 percent of all housing units. The one percent and five percent samples are combined to provide a nationally representative sample with detailed information on 6 percent of the U.S. population.

9. There were changes in the classification system of the detailed occupations used by the Census between 1979 and 1993. A transformation of this system was necessary to make comparisons between the two years available. The U.S. Bureau of the Census Technical Paper 59 was used in this process.

10. The female share of the workforce in the PUMS sample increased from 43.18 to 47.29 percent over this time period.

11. A 60 percent cutoff would result in 59 occupations that have statistically more females than in the labor force not classified as FD in 1980 and 109 in 1990. Adding 5 percentage points to the percentage of females in the labor force would result in 3 occupations that have statistically more females than in the labor force not classified as FD in 1979 and 52 in 1990. In addition, in 1980 there would have been three occupations with statistically the same number of females as in the labor force classified as FD and in 1990 there would have been one. 
12. A full derivation of the statistical model is available from the author.

13. The results from the reduced form estimation of the occupational choice and labor force participation decision are available in the Appendix.

14. One would expect to observe a trade off between benefits and wages. However, only the offered wage is observed. As high wage workers value the tax benefit of nonpecuniary income at a higher level, these workers will be more likely to make the wage/benefits tradeoff.

15. There is more evidence for the latter explanation as the FD wage premium becomes a small FD penalty when the coefficients from the 1993 wage equations are combined with the 1979 data to estimate a predicted wage differential. 


\section{REFERENCES}

Atrostic, B. K. (1982), "The Demand for Leisure and Nonpecuniary Job Characteristics," American Economic Review 72(3), 428-440.

Beller, Andrea H. (1982), "Occupational Segregation by Sex: Determinants and Changes," Journal of Human Resources vXV11(3), 371-392.

Bergmann, Barbara (1974),“Occupational Segregation, Wages, and Profits when Employers Discriminate by Race or Sex,” Eastern Economic Journal 1 (2), 103-110.

Blau, Francine D., Marianne Ferber and Anne E.Winkler (1998), The Economics of Women, Men, and Work, (Upper Saddle River, New Jerssey: Prentice- Hall).

-- and Andrea H. Beller (1988), "Trends in Earnings Differentials by Gender, 1971-1981," Industrial and Labor Relations Review 41(4), 513-529.

Bowen, William G. and T. Aldrich Finnegan (1969), The Economics of Labor Force Participation, Princeton, N. J., (Princeton University Press).

Cain, Glen G. (1986), "The Economic Analysis of Labor Market Discrimination: A Survey," in The Handbook of Labor Economics, eds. Orley Ashenfelter and Richard Layard, (The Netherlands: North-Holland), 693-785.

Chiswick, B, Facklar, J., O’Neill, J., and Polachek, S. (1975), " The Effect of Occupation on Race and Sex Differences in Hourly Earnings", Review of Public Data Use 3(2), 2-9.

Heckman, James (1974), "Shadow Prices, Market Wages, and Labor Supply," Econometrica, 42(4), pp. 679-694.

Hotchkiss, Julie (1991), "The Definition of Part-time Employment: A Switching Regression Model with Unknown Sample Selection”, International Economics Review, 32(4), 899917.

Johnson, George and Gary Solon (1986), “Estimate of the Direct Effects of Comparable Worth Policy," American Economic Review 76 (5), 1117-1125.

Killingsworth, Mark R. and James J. Heckman (1986), "Female Labor Supply: A Survey", in The Handbook of Labor Economics, eds. Orley Ashenfelter and Richard Layard, (The Netherlands: North-Holland), 103-204.

Lee, Lung-Fei (1978), “Unionism and Wage Rates: A Simutaneous Equations Model with 
Qualitative and Limited Dependent Variables," International Economic Review 19(2), 415-432.

McPherson, David A. and Barry T. Hirsch (1995), "Wages and Gender Composition: Why Do Women's Jobs Pay Less?," Journal of Labor Economics, 13(3), 426-471.

Mincer, Jacob and Solomon Polachek (1974), "Family Investments In Human Capital: Earnings Of Women", Journal of Political Economy, 82(2), Part II , S76-S108.

Pencavel, John (1986), "Labor Supply of Men: A Survey", in The Handbook of Labor Economics, eds. Orley Ashenfelter and Richard Layer,( The Netherlands: North Holland), 3-102.

Pitts, M. Melinda and Ann A. McDermed (1994), "Is There Such a Thing as Women's Work?" unpublished manuscript.

Polachek, Solomon William (1981), “Occupational Self-Selection: A Human Capital Approach to Sex Differences in Occupational Structure" Review of Economics and Statistics 63: 6069.

Polachek, Solomon William (1995), "Human Capital and the Gender Earnings Gap: A response to feminist critiques" in Out of the Margin: Feminist Perspectives on Economics, eds. Edith Kuiper and Joland Sap with Susan Feiner, Notburga Ott, and Zafiris Tzannatos (London: Routledge, 1995) pp. 61-79.

Polachek, Solomon William and W. Stanley Siebert (1993), The Economics of Earnings, (Cambridge University Press).

Rees, Albert (1993), The Economics of Work and Pay, (Harper and Row, 1979).

Rosen, Sherwin (2002), Markets and Diversity. The American Economic Association Presidential Address. Presented by Edward Lazear.

Sorenson, Elaine (1989), "Measuring the Pay Disparity Between the Typically Female Occupations and Other Jobs: A Bivariate Selectivity Approach," Industrial and Labor Relations Review, 42 (4), 624-639.

---. "The Crowding Hypothesis and Comparable Worth (1990)," The Journal of Human Resources, vXXV(1), 155-89.

U.S. Bureau of the Census (1989), Technical Paper 59. The Relationship Between the 1970 and 1980 Industry and Occupation Classification Systems, (U.S. Government Printing Office, 
Washington, DC). 